\title{
A "Closed Corporation Law" for California
}

\author{
Roland Adickes*
}

$\mathrm{T}$ HE FACTUAL SETTING in which "closed corporations"1 are formed and operated differs substantially from that in which publicly held corporations function. Yet closed corporations in California are subject to the General Corporation $\mathrm{Law}^{2}$ and the Corporate Securities Law, statutes designed for publicly held corporations. The issuance of securities, the internal organization, and the day-to-day operation of a closed corporation are thus subject to rules designed for another game.

This article will propose rules designed expressly for closed corporations. The concept of a closed corporation law is not new. More than seventy years ago, Germany developed such a law which has been imitated by a number of countries including France, Italy, Belgium, and Switzerland. ${ }^{4}$ Great Britain and Canada have special statutes governing "private companies." There are also a number of American statutes which contain special provisions for closed corporations. ${ }^{\circ}$ Particularly noteworthy among these is the Business Corporation Law of North Carolina. ${ }^{7}$ All of these laws are designed to deal with the same problem: how to permit a small group of businessmen to obtain the benefits of limited liability quickly and at a reasonable cost, thus encouraging small business enterprise and facilitating joint ventures by large enterprises without at the same time exposing the public at large to the danger of stock swindles.

The proposed closed corporation law set forth in this article is designed to be an integral part of California's existing corporation law and the law regulating securities. It presupposes the continued existence of

*M.A., 1958, J.D., 1961, University of Chicago; Associate Counsel, Division of Real Estate State of California. The author was employed for six months as a deputy commissioner in the Division of Corporations. The Commissioner of Corporations generally disclaims responsibility for private publication by any current or former deputy. The views expressed here are those of the author and do not necessarily reflect the views of the Commissioner.

IFrequently the term "close corporation" is used. See generally, O'NEAI, Crose CoRPORATTONS (1958).

2 CAI. CORP. CODE $\$ \S 100-6804$.

3 CAL. CoRP. CODE $\$ \S 25000-6104$.

4 GESELISCHAFT MITT BESCHRÄVRTER HAFTUNG-GeSETZ 1 (Hueck ed. 1964).

5 Companies Act, 1948, 11 \& 12 Geo. 6, c. 38; Can. Rev. Stat. c. 53 (1934).

61 O'Near, op. cit. supra note 1, § 1.14; Bradley, Toward a More Perfect Close Corporation-The Need for More and Improved Legislation, 54 Geo. L.J. 1145, 1146 (1966).

7 N. C. GeN. Stat. ch. 55, §§ 55-1 to -175 (1965). 
the General Corporation Law and of the Corporate Securities Law. The Uniform Securities Act has frequently been proposed as a replacement for the present California regulatory scheme; one of the justifications advanced for this proposal is that the uniform act would facilitate issuance of securities by closed corporations. It is thus important to consider the justification for the continued existence of present statutory provisions, which are complementary to the proposed closed corporation law. Therefore, part I of this article compares the philosophy underlying the California regulatory scheme to that underlying the Uniform Securities Act. Part II discusses the proposed closed corporation law's genesis in existing administrative regulations, while part III summarizes the major innovations contained in the proposed draft. Part IV contains the draft of the proposed law, together with a section by section commentary.

\section{I}

\section{MINIMUM QUALITY CONTROL OF SECURITIES UNDER THE CALIFORNIA SECURITIES LAW}

The California Corporate Securities Law is the legal basis for a public service-minimum quality control of securities-not provided by any other state in the Union. The basic philosophy behind the California regulatory scheme is that the "seller shall beware-not the buyer." attack on the Corporate Securities Law, framed in terms of the "almost unlimited discretion" of the Commissioner, ${ }^{9}$ is in fact directed against this underlying philosophy which requires the seller to prove that his securities are of acceptable quality before lie may offer them on the market.

The Uniform Securities Act is premised on the contrary view. ${ }^{10}$ This

8 Pearce, California Corporate Securities Law vs. Proposed Uniform Securities Law, 9 Hastings L. J. 1, 6 (1957).

9 Edwards, California Measures the Uniform Securities Act Against Its Corporate Securities Law, 15 Bus. LAw. 814, 818 (1960).

$10 \mathrm{~A}$ bill embodying this act was introduced in the California Legislature as Assembly Bill No. 1551, 1961 Regular (General) Session. The supporters of the umiform law claim that the existing Corporate Securities Law suffers from the following defects: 1) Vague standards that make it impossible for legitimate businesses to predict whether their proposed issue of securities will be approved; 2) lack of uniformity with the laws of other states and the federal government; 3 ) uncertainty as to when a permit is required and the extent and duration of possible civil liabilities if a required permit is not obtained or is defective; 4) inadequate regulation of secondary offerings.

These points reflect an inaccurate understanding of how the present law works; in addition, the proponents of the uniform law are overly optimistic in their belief that the uniforn law would solve any of these supposed defects. I believe that the defenders of the present law have adequately refuted these attacks. See Ellis \& McCloskey, The Future of Corporate Securities Regulation in California-Effect of Proposed Uniform Act, 12 Hastivgs L.J. 256 (1961); Pearce, supra note 8. 
act, like the federal securities regulation laws ${ }^{11}$ is primarily a disclosure statute. It is based on the theory that if all the relevant facts about a company and its proposed offering are presented to the prospective buyer, he will be adequately protected.

\section{A. The Commissioner's Discretion}

Considerable controversy exists over the contention that the carefully drafted language of the uniform act would limit the scope of the Commissioner's discretion more than the Corporate Securities Law. ${ }^{12}$ This contention is the principal criticism of existing California law, but a close examination reveals that it has little merit.

The moment we try to describe a multitude of actions which an administrative or judicial official nnay take under varying circumstances, we are forced to use general terms, sucl as "in the public interest,"13 "reasonable,"14 "fair, just and equitable,"15 "in furtherance of justice,"10 and "in the discretion of."17 In the field of securities regulation, the discretion conferred by the general terms of the uniform act-"in the public interest," coupled with a finding of "fraud"18_is as great as that conferred by terms like "fair, just and equitable,"10 or, for that matter, by any other general term. All of these terms point in the general direction of the result sought to be achieved. None of them, taken by itself, permits certainty in predicting what the result will be in a given situation. At best, the uniform act offers only a different imprecise general standard. ${ }^{20}$

Moreover, if the present law does contain some defects, it appears that they could be eliminated by some imaginative amending. The uncertainty over the duration of civil liability, for example, is dealt with in Chapter Five (Curative Powers) of the proposed Closed Corporation Law.

11 The two most pervasive federal securities regulation laws are the Securities Act of 1933, 48 Stat. 74 (1933), 15 U.S.C. \& 77a-aa (1964) and the Securities Exchange Act of 1934, 48 Stat. 881 (1934), 15 U.S.C. \& 78a-hh (1964).

12 Edwards, supra note 9, at 821-23; See 1 O'NEAI, op. cit. supra note 1 , at 25 n.19 (1964 Supp.).

13 Assembly Bill 1551, $\$ 25306$ (a), Cal. Legislature, Regular (General) Sess. (1961).

14 CaI. Bus. \& Prof. COde \$ 11018.5 .

15 Car. Corp. Code \$ 25510.

16 Cax. Code of Civ. Proc. $\$ \$ 473,576$.

17 Cax. Code of Civ. Proc. \$ 437c.

18 Assembly Bill 1551, \$ 25306(a), Cal. Legislature, Regular (General) Sess. (1961). 19 CaI. Corp. Code $\$ 25510$.

20 Louis Loss, the chief draftsman of the uniform law felt that its standards would give the commissioner a discretion short of the "fair, just and equitable" standard. Ellis \& McCloskey, supra note 10, at 263-64. The former Commissioner of Corporations, on the other hand, "has offered as his judgment that any offering that could be properly denied under the "fair, just and equitable' test could also be denied under the uniform act." Id. at 263. It should be obvious that both of these opimions merely expressed what their authors desired the term "in the public interest," combined with the "fraud" test, to mean. The term itself easily accommodates these and countless other interpretations. 
Because the Commissioner's discretion under the uniform law would be no less than that allowed by existing law, this discretion cannot be the real thrust of the attack on the present law. The proponents of the uniform law may wish us to beheve, and may indeed themselves believe, that this is the issue. In fact the issue is whether the burden of establishing the acceptability of securities is to be placed on the seller.

\section{B. Individual Responsibility and Social Efficiency}

Former Commissioner Sobieski in his testimony supporting the uniform law characterized the Commissioner's power under the Corporate Securities Law as "paternalistic."21 Mr. Sobieski's choice of words indicates that the real desire of the proponents of the uniform act is to return Califorma to something approaching the philosophy of caveat emptor. That is, they would require only that issuers of securities fully inform the public as to the terms of the offering and the nature of the business of the offeror. This would leave the judgment of whether the security meets minimum quality standards to the investor, rather than to the Commissioner of Corporations. A rationale which is frequently advanced in support of this philosophy is the need for individual responsibility. Let the buyers make the decisions for themselves: "Responsibility is good for a man."22 However, the question is not whether individual responsibility is desirable or undesirable as an abstract proposition. Rather, the question is whether the individual buyer has the capacity to defend himself against exploiters in the security market if he is given only the protection offered by disclosure statutes. Even if the buyer can in fact protect himself, it may still be that the cost of this protection more than offsets the gains to be expected from the greater "liberty" permitted to the crafty. What the supporters of the uniform act fail to grasp is that the choice between private or state activity in a given field, or between different forms of state activity, should be dictated by considerations of overall efficiency-obtaining the most goods and services for the least total expenditure. From the point of view of economic efficiency, it is irrelevant whether the services are rendered by a public agency or by a private firm, so long as the agency or firm chosen to render the services does so at the least total cost to society.

The supporters of the philosophy of caveat emptor argue that lack of skill and knowledge is irrelevant since potential buyers can hire experts to perform the necessary investigation. ${ }^{23}$ In another context this might be an efficient procedure. But the expense of an analysis of an issue of securities, as effective as that made by the Division of Corporations,

21 Edwards, supra note 9.

22 Stigler, The Unjoined Debate, 3 CHucago TODAY 2, 8 (1966).

23 Ibid. 
would by far exceed the amount even a relatively wealthy investor could afford in relation to the size of his planned investment. The minimum quality control exercised by the Division of Corporations benefits all potential California investors. A comparable screening done by even the largest private firm in this line of business in California would, by the nature of the system, be available only to its customers. If this service were provided by a multitude of private firms, the total cost would, due to the multiplication of effort, be greater to society than the cost of the service rendered by the Division of Corporations.

Putting the question of cost to one side, there is a further objection to the disclosure system. The numerous private firms of stockbrokers and investment counsel engaged in investment advising cannot adequately protect investors because they cannot ultimately provide minimum quality control. Private firms principally deal with advice on issues above the minimum requirements. If they attempt to engage in minimum quality control, they are liandicapped. Typically they earn part of their income from the sale of securities and are not financially responsible for the product they sell. The competitive pressure from other firms which are similarly situated would result in a lowering of the standards of quality. Tucker automobile securities must have been considered to be of acceptable quality by most stockbrokers and investment counsel in other states, because twenty million dollars worth were sold. This offering was subject to the federal disclosure act. The Division of Corporations denied its permit for the Tucker securities and thereby protected California investors from this "fraud upon the purchasers." only is Cahfornia's minimum quality control with its "let the seller beware" philosophy more economical than other systems, it is also more effective in keeping securities of marginal quality off the market.

Whatever the reasons may liave been for the development of caveat emptor, there is now a growing feeling that there is no compelling social policy requiring that a seller be free to devise, by the expenditure of time and money which he must recover in the price, a method for making that look good which is bad. As a corollary, there is also a growing feeling that a wide latitude for outright deception, or for other methods of taking advantage of the limited investigative resources of individual buyers, is not indispensable to an efficient exchange of goods and services. ${ }^{25}$ Like the resources employed in "want creation,"

\footnotetext{
24 N. Y. Times, Aug. 1, 1947, p. 28, col. 3; see Pearce, supra note 8, at 9.

25 See, e.g., S. 985, 89th Cong., 2d Sess. (1966) (the "truth-in-packaging" bill, passed by the Senate, June 19, 1966, and in a weaker form by the House of Representatives October 3, 1966).

26 Galbraith, The Afrluent Society 160 (1958).
} 
sellers to make bad goods look passable, or passable goods look excellent, are wasted. Caveat emptor would require the buyer to expend equivalent resources to find out in turn that the "passable" goods are bad and that the "excellent" goods are merely passable, which leaves the matter exactly where it started.

California's Corporate Securities Law preceded the recent trend against this form of waste by some fifty years. It puts the burden on the seller to prove to the buyer's public representative that his product is good, or at least passable. ${ }^{27}$ The seller is not allowed to gamble on getting by, in the hope that, due to the disproportionate cost of an adequate investigation, people will not become aware of the true nature of his product until the statute of limitations has run. If his product does not pass muster, he is siniply, and properly, thrown out of the California market, the most desirable securities market in the nation.

Since California's minimum quality control of securities under the Corporate Securities Law is less costly, more effective, and more convenient for the individual buyer than regulatory systems relying principally on disclosure provisions, it is preferable by any current standard (excepting only the seller's natural preference for caveat emptor) to the various types of regulation used elsewhere $\mathrm{m}$ the nation and to the uniform law.

\section{II}

GENESIS OF THE CLOSED CORPORATION LAW

The regulatory philosophy exemplified in the California Corporate Securities Law, while desirable in the context of offerings to the general public, is not necessarily preferable in the context of the closed corporation. The purpose of minimum quality control is to protect the uninformed investor from offerings which are by their terms unfair to the investor or which miglit result in loss of his investment under circumstances not likely to be foreseen by the average investor, even if he is armed with all relevant information. While the closed corporation may include among its investors persons who are not fully informed, the typical investor in a closed corporation will himself be active in the management of the enterprise. He will therefore be peculiarly competent to protect himself against either unfairness in the terms of the offering or fraudulent business practices likely to lead to the loss of his investment. Furthermore,

\footnotetext{
27 Securities offered through a firm underwriting are an exception to this rule. They require no permit because the underwriter is not offering securities of his own issuance. See Cac. CoRp. CODE $\$ 25500$. Since the underwriter will have to keep any part of the issue he is unable to market, he will agree to a firm underwriting only if the securities in question are of excellent quahty. There is no need for securities of this type to be screened by the Commissioner.
} 
because of his participation in management, the typical investor in closed corporations is to some degree responsible for any possible loss. It is unnecessary to give him the same degree of protection afforded to the blameless investor in an enterprise over which he has no effective control. Recognizing this, the Division of Corporations has evolved a substantial body of administrative "law" relative to the closed corporation; for the most part, this "law" is transmitted only by oral tradition, or, to a certam extent, by confidential intra-office memoranda.

An attorney discussing his chent's apphication for a permit to issue securities with the Commissioner's staff will immediately encounter terms hike "open permit," "closed permit," and "closed group," which are not found in the Corporations Code or in the regulations. ${ }^{28}$ The "closed permit" is, by the Division's practice, defined as a permit issued to a corporation allowing it to issue securities only to those persons named in the permit. To obtain such a permit, a group of persons must qualify as a "closed group." In the Division's practice, a "closed group" may be a group of people related by blood or marriage. It may be a group of people who have some other kind of sustained relationship such as long established common business interests, or friendship, or acquaintance througl social organizations, or any combination of these factors. The size of the community in which the venture is launched may be an additional factor. The maximum number of people ordinarily considered compatible with the concept of a "closed group" will be between twenty to thirty persons. Occasionally higher numbers, but still well below one hundred, have been considered a "closed group." Usually, at least several of these elements are required before a group will be considered "closed."

To issue a closed permit, the Division requires less detailed information about the plan of business and proposed financing than in the case of an "open permit." The rationale for this relaxation of the standards is that there is hittle chance of unethical deahings or outright fraud among such persons. The risk of fraud is much greater when a promoter or an already organized corporation is permitted to sell securities to people to whom they feel no special obligation.

The proposed closed corporation law codifies this body of useful administrative practice and removes some of the unnecessary costs presently incurred ${ }^{29}$ in organizimg a business owned by a small group of persons. The corner drugstore, the three-man contracting corporation, the fivedoctor pharmaceutical research corporation, and similar corporate enter-

2810 Cal. Admon. Code $\S \S 300-860$.

29 The most important of these costs are the executive and legal time required for preparation of the application and for negotiations with the Division, and, perhaps most importantly, processing time. 
prises which utilize the corporate form principally for insulation from personal hability, rather than for raising capital, present no appreciable threat of fraudulent stock sales to the public at large. The same is true of the joint venture between two or more corporate giants. Yet all of these enterprises must presently apply in the same manner, and are subject to substantially the same conditions, as those enterprises which seek the widow's and the orplan's dollar for financing their original plant or expansion.

As for the problem of preventing the participants in a closed venture from defrauding each other, it is questionable whether the current admimistrative practice really provides more effective protection than that built into the proposed system. Moreover, adequate protection of the public at large against stock swindles in which the stock involved was originally sold to a "closed group" has been built into the proposed system..$^{30}$ By contrast, the present law relies upon the somewhat illusory protection of the escrow condition. ${ }^{31}$ The escrow condition is usually imposed on new, unproved enterprises, and it is nearly always imposed where promotional stock is involved. It is also imposed on existing enterprises which desire to change into corporate form, but do not wish to submit a detailed account of their financial history in preceding years, or their present budget and plan of business. Many firms are unwilling to submit these reports because they find it too time-consuming to do so, or because they do not wish to let their competitors gain access to this information, or because they, indeed, have something to hide.

The purpose of the escrow condition is to prevent a transfer of stock of unsubstantiated value to the public. In theory this result is reached because the owner of the escrowed stock must obtain the approval of the Commissioner for the transfer and must, at that time, if required by the Commissioner, fully disclose the financial data necessary to evaluate the stock. In practice, however, when the time of transfer arrives, the Commissioner's staff frequently is faced with the problem that the origmal file, except for a microfilmed copy of the permit and any orders of the Commissioner, las been destroyed as "useless or obsolete."32 Moreover, even when the file is available, the Commissioner's office may be swamped with new apphications, with the result that at the point which is critical for purposes of protecting the public-the transfer in escrow-little more than routine attention can be given to the facts in-

30 See Chapters One and Two of proposed Closed Corporation Law.

31 10 CAT. ADMTIN. CODE $\$ \S 407-21$. Requiring that the stock be placed in escrow prevents the persons named in the permit from freely transferring the stock to members of the general public. If a shareholder desires to transfer such stock, he must first obtain a permit from the Commissioner for a transfer in escrow.

82 CAI. CORP. CODE $\$ 25315$ permits such destruction four years after filing. 
volved in each transfer. ${ }^{33}$ Thus, the escrow condition does not seem to protect the public against the sale of dubious securities of closed corporations to any higher degree than would the proposed closed corporation law with its built-in escrow condition.

It is common knowledge among a substantial number of members of the California State Bar that the standards for imposing the escrow condition are so vague that it is impossible to show an abuse of discretion by the Division. The result is unreasonable discrimination, definitely unintentional on the part of the Division, but nevertheless unreasonable from the standpoint of the party affected. In my opinion, this discrimination can be avoided to a certain extent by substituting the relatively tight rules of the proposed closed corporation law for the Commissioner's broad discretion..$^{34}$ The proposed law does away with the irritating factor of the seemingly arbitrary inposition of the escrow condition, since all closed corporations will be subject to the same limitations.

Because of the lighter work load which would result from the exemption of some corporations from the permit requirements under the proposed law, the Commissioner's staff would be able to examine carefully the circumstances of eacli proposed transfer and could give full protection to the public at this critical point. I estimate that approximately fifty per cent of the applications for permits currently filed with the Division could qualify for organizing under the proposed closed corporation law. Even if only one-half of this number should actually choose to organize under this law, it would reduce the Division's work load by one-fourth. The time saved could then be used to give more than routine attention to transfers in escrow and to transfers of the securities of corporations organized under the proposed law.

It should be noted that the proposed law is not intended to supersede present practice entirely. It is intended as an alternative vehicle to be used by those small businesses which find it preferable to the present systein. Some sinall businesses, to obtain a permit escrow-free, may still submit apphications which satisfy all the requirements of the Division for submission of business and financial records.

The Commissioner of Corporations has announced to the California Bar that the Division will undertake a study of "areas where the Corporate Securities Law has not proven adequate to meet current needs,

33 This has been widely recognized by the profession for a considerable time. See California Contmutno Educatton of the Bar, Advising California Bustness EnterPRISES 535 (1958).

34 This statement should not be misread into a general attack on the scope of the Commissioner's discretion. The special circumstances of the closed corporation permit a uniform solution of the problem by making closed corporation securities unmarketable by definition, but in other instances a broad discretion is indispensable. 
as well as ... those areas in which it has proven overly stringent and in need of relaxation." 35 The Commissioner referred particularly to "the possibility of providing limited exemptions for some small offerings" and "an examination of the existing rules which provide for the perpetual voidness of securities which contravene the Corporate Securities Law .... ."36

This article proposes a solution for the first of these problems by the creation of a special form of corporate entity, the "closed corporation," with a special form of unmarketable securities, designed to let small groups of businessmen organize in corporate form without the need of applying for a permit from the Commissioner. If the closed corporation law were adopted, the spectrum of securities issued or sold in California would be divided into three major groups: (1) The "cream of the market," firmly underwritten by California brokers and sold without permit; (2) the "skimmed milk type securities," carefully screened by the Division of Corporations, and sold under permit; and (3) closed corporation securities, marked as such, and forbidden by law to enter the market.

\section{III}

THE GENERAI PROVISION OF THE PROPOSED IAW

A brief summary of the main features of the proposal may be helpful at this point.

\section{A. Exemption from Permit Requirement}

The closed corporation law would create a partial exemption from the Corporate Securities Law. A closed corporation would need no permit from the Corporations Commissioner to issue its securities to the number of stockholders permitted by law. This would be true for its initial issue as well as for subsequent issues, but the exemption would extend only to securities issued to the twenty or less shareholders permitted in a closed corporation. Any security issued to any person beyond the twenty persons permitted by the law, would be subject to the Corporate Securities Law.

Further, a transfer of closed corporation securities which would cause the number of shareholders to exceed twenty (ten, where the securities are issued for intangible property without an established earnings record) after completion of the transfer would require a permit from the Commissioner. Transfers by bequest, inheritance, bona fide gift in writing, or transfer under a security agreement filed with the Secretary of State, would be excepted.

35 The Recorder, April 1, 1966, p. 1, col. 4.

36 Ibid. 


\section{B. Penalties}

The consequences of an issue or transfer in noncompliance with the provisions of the closed corporation law would be more severe than the penalties for an issue without a permit, or a failure to conform to a permit, under the Corporate Securities Law. The transfer or issue would be voidable at the instance of the transferee or issuee, without limitation in time, as under the Corporate Securities Law. But avoidance, if the transferee or issuee was not in pari delicto, would entitle him to recover three times the security's value, at either the time of the issue or transfer. In addition, criminal penalties equivalent to those of the Corporate Securities Law would be provided. A private treble damage action would be available for any non-compliance causing damage to any third party. The privilege of exemption from the Corporate Securities Law would be paid for by strict compliance with the closed corporation law.

\section{Curative Poterers}

To avoid undue hardship, the closed corporation law provides for a method by which either the corporation itself or the person responsible for the non-compliance could apply to the Commissioner of Corporations for a "curative order." The apphication would be required to set forth the facts of non-compliance. Notice would be given to all stockholders and to all known creditors of the closed corporation. The persons notified would have thirty days in which to demand a hearing, but even if none of these persons demanded a hearing, the Commissioner might decide that a hearing is needed. If the Commissioner found, either with or without a hearing, that curing the noncompliance would be fair, just and equitable under the circuinstances, he would be required to issue the curative order. The effect of such an order would be to cure the non-compliance nunc pro tunc. The Commissioner's decision would, of course, remain subject to review by administrative mandamus.

\section{Restitution Fund}

The proposed law would afford greater convenience in obtaining the benefits of limited liability to a large class of businessmen. In return, this class would be called upon to indemnify persons damaged as a result of a failure to comply with the proposed law. This indemnification would be accomplished by establishing a restitution fund administered by the Commission. As a practical matter the persons most likely to be benefited by a restitution fund would be innocent members of this same class, because they, rather than the general investing public, would hold the majority of the stock in closed corporations or would otherwise be dealing with closed corporations. However, the restitution fund's central 
purpose would be the protection of the public against worthless securities. The restitution fund is patterned after the Real Estate Research and Recovery Fund, created for indemnifying the public for danages suffered due to fraud or dishonest dealing by real estate licensees. ${ }^{37}$ It differs from the Real Estate Recovery Fund in that it does not put the financial burden of prosecuting a claim on the dainaged party. Frequently such a party is unable to gamble additional funds on recovery, especially where the damages themselves are large enough to hurt but are too small in relation to the cost of recovering them from the guilty parties. Under the proposed law, the damaged party would be free to seek recovery on his own, as an alternative to recovery from the restitution fund. As a practical matter, this would most often be the case, since no treble damages could be recovered froin the fund.

Proceedings to obtain reimbursement from the fund would be initiated by an application to the superior court of the county where the damaged party resides. A copy of the application would be required to be served on the Commissioner and on the closed corporation involved. The Commissioner would have to oppose the application if he found that it would not be fair, just and equitable under the circumstances to permit recovery from the fund. If an application were granted, the Commissioner would becoine subrogated to all riglits which the petitioner had under the closed corporation law against the corporation or the responsible persons. The closed corporation and the responsible persons involved could appear and defend as in an ordinary civil proceeding. If the court ordered payment from the restitution fund, the findings on which the order was based would be res judicata agamst the corporation in any subsequent proceeding by the Commissioner on the subrogated claim. If the responsible persons liad been served, the findings would also be res judicata as against thein. This would also be true if they appeared and defended without having been served. Service on the responsible persons would not be required in a proceeding for recovery from the fund, because such a requirement could too easily defeat the purpose of providing speedy recovery. The Commissioner is in a better position to enforce the statute against evasive, responsible persons.

The restitution fund would close a gap which not even the most vigorous enforcement of the current law could close. It is not possible to prevent all frauds. The next best thing is to indemnify the victims of those frauds which the law was unable to prevent. With its combination of enforcement by private treble damage action and assurance of restitution in case of unpreventable frauds, the closed corporation law would give more protection to closed groups than the present system.

37 CaI. BUs. \& Prof. Code $\$ \$ 10470-83$. 


\section{IV}

THE PROPOSED CLOSED CORPORATION LAW ${ }^{38}$

\section{A. Chapter One. General Provisions}

Section 7100. This part shall be known and may be cited as the "Closed Corporation Law."

Section 7101. The general provisions of the Corporation Code, the provisions of the General Corporation Law (Title 1, Division 1 of this Code) and the provisions of the Corporate Securities Law (Title 4, Division 1 of this Code) shall apply to closed corporations, except as otherwise expressly provided by this part.

Comment: The proposed law provides for a special form of corporation within the framework of the general corporation law, much like the non-profit corporation. Section 9002 was used as a pattern.

Section 7102. A closed corporation may only be formed under this part.

Section 7103. The provisions of the Closed Corporation Law shall be construed so as to achieve its primary purpose of protecting the public.

Comment: This section declares the legislative intent. The Closed Corporation Law is a substitute for part of the function presently performed by the Division of Corporations under the Corporate Securities Law. While its effect is to provide a convenient corporate form for small groups of businessmen, its rnain purpose remains protection of the public, though in a form different from that currently employed.

38 The proposed law is drafted to facilitate locating the case law which may be expected to develop under it. Most lawyers will agree that, once a relevant case has been found the best method of locating all other relevant decisions is by the use of the citator. When the search starts from a statutory provision, it should be just as easy to locate relevant case law.

For many California statutes this is not true, because the draftsmen failed to designate each legal rule contained in the section, or its main components, by a separate number or letter, or both. Thus, when searching the citator for cases on one of the eight legal rules contained in section 473 of the Code of Civil Procedure, a prime example of such lack of organization, it becomes necessary to go through all the cases relating to the other seven rules: Since the section has no subdesignation for these rules, neither does the citator.

I have on occasion given a subdesignation even to parts of sentences, when it appeared that disputes about the application might be confined to one such part without necessarily involving the remaining parts. I have generally used letter designations for whole sentences and number designations for parts of sentences, but the use has not been entirely systematized. The method is similar to that used in division 8 of the Cahiformia Commercial Code.

The breakdown into smaller identified units of information should also prove helptul in eventually programming the citator to a computer. See generally Allen, Logic-Language-Law, in CONIPUTERS \& THE LAw 79 (1966). 
Section 7104. In addition to the matters required by Section 301 of this code, the articles of incorporation of a closed corporation shall state in capital letters the words "A CLOSED CORPORATION" after the name of the corporation.

Comment: This requirement is largely for administrative ease. I expect that the Secretary of State would create a separate section in his office for closed corporations.

Section 7105. (a) Whenever a closed corporation displays its name to the public, it shall display the letters "C.C.," or the words "CLOSED CORPORATION" following its name.

(b) The letters, or words, shall be of the same size as those used to display its name.

Comment: This section is similar to a provision in the Gernan Closed Corporation Law requiring identification of the special corporate form. ${ }^{39}$

Section 7106. (a) Every closed corporation which violates any of the provisions of this part is subject to a fine not exceeding ten thousand dollars.

(b) Any shareholder, director, or officer of a closed corporation who knowingly participates in, or condones, any act or omission in violation of this part, is subject to imprisonment in the state prison not less than one year nor more than five years, or to a fine not exceeding ten thousand dollars, or both.

(c) If no damage was caused to any person, or if the actual damage caused by any violation amounts to less than $\$ 1,000.00$, the violation is a misdemeanor and subject to the penalties for misdemeanors provided by Penal Code Section 19.

Comment: The criminal penalties correspond to those imposed by Section 26103 for violations of the Corporate Securities Law. Criminal liability has been extended to cover any violation of any provision of the Closed Corporation Law. To limit the otherwise overly broad scope of this liabihty all "technical violations" have been excluded by subdivision (c). No violation can be a felony which did not result in actual damages of more than $\$ 1,000.00$ to a inember of the public. Most economic crimes are malum prohibitum, not malum in se. The conduct in question is prohibited because it is likely to damage members of the public in a monetary way. If this danage has not occurred, the malum is not taken seriously by the community, and no district attorney will then prosecute, except for harassment purposes. The proposed section merely reflects these facts of life.

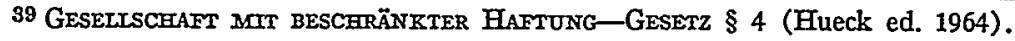


In any event, the criminal provisions are a last resort, to be used against recalcitrant offenders. The main pressure for compliance is expected to result from the treble damage provisions. Since some shareholders in closed corporations tend to have dominant positions without being formally responsible for management, criminal liability has been extended to shareholders.

Section 7107.

(a) (1) Any person who suffers any damages due to the failure of a closed corporation to comply with any provision of the Closed Corporation Law, and

(2) who is not legally responsible for the noncompliance,

(3) may bring an action in the Superior Court of the county where he resides, to recover three times the amount of damages suffered by him,

(4) from the corporation, or

(5) if its net assets are insufficient to fully satisfy the claim

(6) from those of its shareholders, directors or officers who are legally responsible for the noncomphance, jointly and severally.

(b) (1) Except when participating in a fraud,

(2) any shareholder, director, or officer legally responsible for a noncompliance

(3) who satisfies more than his share of a claim under this section,

(4) is entitled to contribution, pro rata according to their numbers, from all other shareholders, directors or officers who are also legally responsible for the noncompliance.

(c) The corporation may recover any amount for which it has become liable under this section, from any person legally responsible for the noncompliance.

(d) Causation of damages shall be determined by the same standards as under Section 7608.

Comment: This section provides the basic enforcement tool of the Closed Corporation Law, the treble damage action. The deterrent effect of criminal penalties is questionable. The profit motive frequently outweighs it. As a rule it is only the grossest type of an offense which results in a conviction. Treble damage actions are more likely to deter. When it is clearly unprofitable to disobey the law, we may expect careful compliance. 
A closed corporation is not a layman's plaything. A business which uses this vehicle must obtain expert legal advice and follow it. The corporation is strictly liable for any damages caused to any person by its noncompliance with the Closed Corporation Law. "Any person" includes a shareholder of the corporation who has not become responsible for the noncompliance by participation in the conduct of the business.

If the corporation has insufficient net assets, then those of its shareholders, directors or officers who are "legally responsible" for the noncompliance are jointly and severally liable for the treble damages. The term "legally responsible" 40 has been chosen to give leeway to the courts. It is impossible to make a precise rule as to when shareholders should be liable. Each case will turn on its facts. The standard of causation to be applied in cases arising under this section should be the same, however, as that applied under Section 7608 (claims against the restitution fund), because a judgment under that section is res judicata if the Commissioner pursues his subrogated claim under Section 7107. If the corporation pays the treble damage claim, it is entitled to recover in turn from the persons legally responsible for the noncompliance. Persons found legally responsible for a noncompliance are entitled to pro rata contribution from others found equally responsible.

The determination of "net assets" also is left to the courts. The purpose is to protect creditors in the regular course of business. Since a treble damage action occasionally may mean the end of the corporate business, this is especially important.

The penalty is harsh. To permit a closed corporation to escape this penalty by due diligence, Chapter Five (Curative Powers) provides a method by which a closed corporation can avoid treble damage actions by filing an application for a curative order with the Commissioner. Any pending treble damage action may be stayed once such an application is filed, if the applicant makes a bona fide offer of restitution. Actual use of the treble damage action will therefore be infrequent. Its main influence is expected to be the creation of pressure for bona fide offers of restitution.

Section 7108.

(a) (1) No person seeking indemnity from a closed corporation under Section 830 for a judgment against him under Section 7107 shall be entitled to such indemnity,

(2) unless the court finds that the person was not legally responsible for the noncompliance in question.

${ }^{40}$ This concept is similar to that of "legal cause." See Restatenent (SeCOND), Torrs $\S \S 431-32$ (1965). 
(b) The finding required by subdivision (a) is also required if indemnity is sought after a suit under Section 7107 has been settled.

Comment: Treble damage actions may occasionally be abused for harassment, hike any other legal action. In such a situation the corporate official so attacked should be indemnified by the corporation, if there was no failure to comply or if he has not been found legally responsible for the alleged noncompliance.

Section 7109. Section 834 is not applicable to any action brought under Section 7107.

Comment: Section 834 limits shareholders' actions to shareholders who held shares at the time the noncompliance occurred. This is contrary to the intent of the closed corporation law, which puts the burden to make restitution on the party who acted wrongly, and does not permit automatic cut-off of the rights of aggrieved persons, or the cure of an offense by the mere passage of time or by the fortuitous circumstance that it is discovered after the stock has changed hands.

Section 7110. All hearings held by the Commissioner of Corporations pursuant to this part shall be conducted in accordance with the Administrative Procedure Act (Title 2, Division 3, Part 1, Chapter 5 of the Government Code) and the Commissioner shall have all the powers granted therein.

Comment: The trend towards administrative hearings presided over by an independent hearing officer should be encouraged. If the hearing officer were provided by the agency itself, as the Corporate Securities Law permits, ${ }^{41}$ the matter would become too much of an internal affair within the agency. Independent hearing officers, even though at present they only have the power to make recommendations, are a sound limit to the discretion of the agency.

Section 7111. The Commissioner shall from time to time recommend to the legislature such amendments to the Closed Corporation Law as may appear necessary or desirable.

Comment: Under present theory the legal staff of an agency should concern itself with enforcing the law and leave the making of the law to the legislature. The practice of many agencies is contrary, and for

41 The Corporate Securities Law does not contain the provision found in most California regulatory statutes that all hearings and proceedings must be held pursuant to the Administrative Procedure Act of California. Not infrequently, therefore, senior deputy commissioners are acting as hearing officers. 
sound reasons. Only the lawyers working daily with the statute in question are likely to acquire full knowledge of its defects, whether in matters of detail or even of principle. Logically then, these persons should be encouraged to propose solutions.

This is not interference with or usurpation of legislative functions. Private practitioners working in their spare time presently bear most of the burden of improving the law, except for the limited instances where a segment of the business community retains counsel to draft a law suited to their interests, a method of improvennent which leaves much to be desired.

The proposed law gives the agency the power and the duty to work for its improvement. Proposals from the agency will tend to be as heavily weighted in the public interest as those coming from private groups are weighted in the private interest. The legislature will thus be enabled to chose from both sides whatever it considers desirable.

Section 7112. The Commissioner may establish such rules and regulations as are reasonable or necessary to carry out his functions under the closed corporation law.

Comment: This section has been adapted from Section 25308. While the power to set additional standards for closed corporations is the legislature's, the Commissioner needs rule making power for the implementation of those standards after they have been determined by the legislature.

Section 7113. For the purposes of the Closed Corporation Law the term person includes:

(1) a natural person;

(2) a trust;

(3) an estate;

(4) a partnership, including any syndicate, group, pool, joint venture, or other unincorporated organization through or by means of which any business, financial operation, or venture is carried on and which is not otherwise referred to in this section;

(5) an association;

(6) a company; .

(7) a corporation;

(8) any other legal entity which may be created by statute or judicial decision.

Comment: This section has been drawn from Section 7701 of the Internal Revenue Code of 1954. Section 18 of the Corporations Code was 
not felt to be sufficiently explicit for purposes of the disclosure requirements of Sections $7350-54$, since on its face it includes only a natural person and a corporation.

Section 7114. For the purposes of the Closed Corporation Law the term "entity" includes all meanings of the term "person," as defined by Section 7113, except "natural person" (Section $7113(1))$.

Comment: The term "entity" is introduced for convenient reference to "persons" who are not natural persons, but who are "persons" only by legal fiction.

Section 7115. Any person who files in connection with any application under the Closed Corporation Law any document which is false or contains any material misstatement of fact shall be subject to the penalties provided by Section 7106 .

Comment: This section is substantially copied from the Real Estate Recovery Fund ${ }^{42}$ to obtain the deterrent effect of the criminal penalties.

\section{B. Chapter Two. Formation, Issue and Transfer of Securities}

1. Article One. Issuance. Types of Securities. Permit Requirements

Section 7200. (a) A closed corporation is formed by the issuance of securities in accordance with this part and by filing articles of incorporation pursuant to the General Corporation Law.

(b) After the filing of the articles of incorporation, but before the issuance of securities, the board of directors may pass the resolutions required for the issuance of the securities.

Comment: The closed corporation has no legal existence until its securities are issued. Securities cannot be issued before the corporation has received the entire consideration (Section 7220). A business intending to use the closed form must therefore clarify all its business ties, legal relations, property rights, assemble its assets, and so on, before receiving the benefit of limited liability. Otherwise there is no corporation. Current law on de facto corporations, to the extent that it deals solely with the liability of the de facto corporation to persons who liave entered into contracts with it, remains unafiected.

Section 7201. A closed corporation may, without obtaining the permits required by Section 25500 , Section 25517 , or Section 25153 (b) of this code, issue and sell its securities to not more than twenty persons.

42 Cal. Bus. \& Prof. Code § 10.478. 
Comment: The statutory "closed group" has been set at twenty persons. "Person" includes legal entities. The number chosen would permit the overwhelming majority of California small businesses to take advantage of the new law.

A study of the permit applications to the Division of Corporations would probably show that the greatest percentage of applications comes from corporations with less than ten shareholders. But occasionally the Division has found larger groups, even exceeding forty persons, to be "closed groups." The proposed number seeks to strike a rough balance between these extremes.

I recognize, of course, that in a group of twenty there will frequently be a few "passive investors," who contribute funds to the venture but take no active part in its management. The standards of the Closed Corporation Law for a group of twenty are more stringent than those of the Division of Corporations. For example, the proposed law does not permit promotional stock at all in closed groups over ten persons (Section 7223). In addition, the provisions for private treble damage action (Section 7107) and the restitution fund (Sections 7600-19) protect the passive investors among the group against losses due to the corporation's failure to comply with the standards. Under these circumstances I beheve that the risk of having limited numbers of passive investors in closed corporations can safely be taken.

The figure of twenty is, of course, chosen by feel; experience will show whether it should be reduced to fifteen, or to ten, or whether it may safely be raised to thirty, or forty, or more. This requires a social experiment. But it seems worthwhile, and due to the restitution fund, not unduly risky, to experiment in this area.

Section 7202. Except as provided by Sections 7203, 7204 and 7205 , securities of a closed corporation may be transferred only after first obtaming a permit from the Commissioner of Corporation.

Section 7203. A permit shall not be required for transferring a closed corporation security to any person as long as the number of shareholders of the closed corporation, after completion of the transfer, does not exceed the numbers permitted by Sections 7201 or 7223.

Section 7204. A permit shall not be required for the transfer of closed corporation securities to any person entitled thereto by bequest, inheritance, or bona fide gift evidenced by a written instrument.

Section 7205. A permit shall not be required for transferring 
a closed corporation security pursuant to a security agreement filed with the Secretary of State under the provisions of the California Commercial Code.

Comment to Sections 7202, 7203, 7204 and 7205: A controlled transfer, similar to the current transfer in escrow, is provided where the total number of shareholders would exceed twenty after completion of the transfer. This provision is similar to the exemption for small offerings in the proposed Uniform Securities Act. ${ }^{43}$ The limit is ten shareholders where any promotional securities are involved.

No permit is needed for a transfer resulting from testate or intestate succession or from bona fide gift. Because of death or magnanimity the closed group can grow beyond twenty (ten where promotional securities are involved), but once it has done so, all subsequent transfers for a consideration are subject to the control of the Commissioner.

No permit is needed for a transfer under a properly filed security agreement. A closed corporation security is not an investment security under Section 8102 of the California Commercial Code. It would probably be classified as a general intangible under Section 9106. Thus the only method of perfecting a security interest in a closed corporation security would be by filing a financing statement pursuant to Section 9302; a transfer of possession would be neither necessary nor effective according to Section 9305, Comment 1.

Section 7206. The Commissioner shall by regulation provide for the method and form of application for transfer.

Comment: The Commissioner may find it necessary to adopt special requirements for the transfer permit or may use a procedure similar to the current procedure for transfers in escrow. ${ }^{44}$

Section 7207. (a) Any attempt to issue or transfer, and any issue or transfer of closed corporation securities in noncompliance with any provision of this part is a public offense subject to the penalties of Section 7106, and

(b) shall in addition liave the following legal consequences:

(1) The issue or transfer is voidable at the instance of the issuee, transferee, or their successors in interest at any time without limitations.

(2) The issuee or transferee, or their successors in interest,

(A) if not in pari delicto with the issuer or transferor, (1961).

43 Assembly Bill 1551, § 25402 (b) (12), Cal. Legislature, Regular (General) Sess،

44 10 Cat. Adnotr. Code \& 419. 
(B) shall be entitled to recover from the issuer or transferor three times the value of the security as of the time of the issue or transfer.

Comment: This section applies the sanctions of the Corporate Securities $\mathrm{Law}^{45}$ to the Closed Corporation Law. The sanctions are the same; a security issued in noncompliance is perpetually voidable. The penalty is heavier: three times the value of the security. Strict compliance is required.

The Commissioner's curative powers under Chapter Five make such a provision reasonable. With painstaking care by competent attorneys any closed corporation will be absolutely safe. Any technical violations resulting from bona fide mistake or excusable neglect can be cured by application to the Commissioner. Even where the noncompliance was not above reproach and where, in addition, the buyer has suffered damages caused by the noncompliance, an application for a curative order accompanied by an offer of complete restitution can forestall a treble value action.

A premium is thus set on the most careful compliance with the law. A well advised and law abiding issuer has nothing to fear.

Section 7208. (a) A closed corporation shall have only one class of securities.

(b) Subject to Section 7223 each security shall have the same rights, privileges and preferences as every other security.

(c) Closed corporation securities shall have no par, face, stated, or similarly designated value.

(d) In addition to the securities described in subsection (a) a closed corporation may issue securities pursuant to Section $25102(\mathrm{~b}),(\mathrm{c})$ and (d).

(e) Issue of securities pursuant to Section 25102 (b), (c) and (d) shall not be subject to Sections 7201 or 7223 .

Comment: (a) The corporation for which the closed corporation law was designed is the small group of businessmen, with an occasional passive investor, usually the wife or a friend of one of the active participants. There is no legitimate need for a varied stock structure. Deviations from simple majority control are possible under Section 7309 and Section 7312.

(b) This Subdivision is designed to make unmistakably clear what "one class" is intended to mean.

(c) Value designations of this type cannot serve any useful purpose in a closed corporation. To the occasional passive investor the value 
designation may, indeed, actually be misleading by its association with instruments bearing a fixed value designation, such as promissory notes and dollar bills.

(d) and (e) The issuance of promissory notes is exempted from the Closed Corporation Law to the same extent as from the Corporate Securities Law.

Section 7209. (a) No security of a closed corporation shall be subject to any provisions in the articles of incorporation or the by-laws of the corporation, or in any contract which precludes the holder in any way from recovering in cash, upon transfer, the actual value of the security, as measured by bona fide offer. Any such provision is void.

(b) No right of first refusal (or any similar right) shall be valid, unless it must be exercised with respect to all of the securities offered for sale, and the transfer price paid within thirty days after the party entitled to exercise the right has received notice of the proposed sale.

Comment: This section codifies relevant parts of regulation 407 of the Commissioner. ${ }^{46}$

Section 7210. Closed corporation securities shall not be subject to redemption at the option of the corporation.

Comment: Redemption at the option of the corporation implies a power to buy out minorities. Under the Closed Corporation Law all shares have equal rights. If all are redeemable at the option of the corporation under certain conditions, then a majority could, whenever such conditions exist, buy out the minority against their will.

Section 7211. Closed corporation securities shall not be assessable. 。

Comment: Since full payment before issuance is required by Section 7220 , the assessment provisions of the general corporation law are inapphicable.

Section 7212. The shareholders, directors, and officers of a closed corporation are personally liable, jointly and severally, for all debts, liabilities and obhigations incurred by the corporation until the corporation is formed pursuant to Section 7200 and the entire consideration due for its securities has been fully paid in, received, or performed.

4010 CaL. Admont. CODE § 407. 
Comment: This section is intended to encourage strict compliance with the requirements for formation of a closed corporation. See comment to Section 7200 .

\section{Article Two. Consideration}

Section 7220. No closed corporation shall issue any security before the entire consideration for it has been full paid in, received or performed.

Comment: See comment to Section 7200 and 7212.

Section 7221. (a) The amount of the consideration payable for each share issued by a closed corporation shall be the same as that payable for every other share of the same issue.

(b) Any issue which provides for a higher price per share than the preceding issue is fraudulent, unless the board of directors determines by resolution that the then current value of a share of the preceding issue corresponds to such higher price.

Comment: This section is necessary to prevent circumvention of the rule against differentiated stock structures (Section 7208) by charging different prices for the same number of shares, when this is not warranted by any actual change in the net worth or the earning power of the corporation.

Section 7222. A closed corporation may issue its securities only for any or all of the following considerations:

(1) money paid;

(2) the fair value of labor done;

(3) the fair value of services rendered;

(4) the fair value of debts cancelled;

(5) the fair value of tangible or intangible property actually received by the issumg corporation; or

(6) amounts transferred from earned surplus to stated capital upon the issue of shares as a dividend.

Comment: This section prohibits certain types of consideration for the issuance of shares otherwise allowed by Corporations Code Section 1109. For convenience the section is given verbatim in the body of the Closed Corporation Law, rather than by a recital of exceptions to Section 1109. Transfers from surplus are himited to transfers from earned surplus, as there can be no paid-in surplus in a closed corporation (see Section 7240).

Section 7223. (a) A closed corporation may only issue its 
securities for intangible property when all of the following conditions are met:

(1) the corporation has not more than ten shareholders

(2) the securities issued for intangible property do not exceed $1 / 3$ of the combined number of the securities to be issued and any outstanding securities.

(3) The securities issued for intangible property carry a cumulative waiver of dividend rights and of rights to participate in the distribution of assets in the event of liquidation or dissolution, in favor of all shareholders who have paid cash or its equivalent for their shares.

(b) Patents, copyrights, or other intangible property, which have a monetary value established by a prior earnings record, is not "intangible property" for the purposes of this section.

Comment: (a) This subdivision codifies regulations 372 and 368.2 of the Commissioner. ${ }^{47}$ The number of shareholders has been limited to ten, since the likelihood of having passive investors in such a smaller group is less. Still there will occasionally be passive investors, but limiting the promotional shares to less than a majority, and making it difficult for them to be sold from under the other shareholders by the subordination of their dividend and liquidation rights is likely to protect the passive investors to a degree. Only experience can tell us whether this protection, together with the restitution fund, is sufficient.

If doubts should be overwhelming on this point, further reduction of the total number of persons permitted in sucl a venture, or of the percentage of promotional stock permissible should be considered before eliminating this provision entirely.

(b) This subdivision codifies the relevant parts of regulation $368 . .^{48}$

Section 7224. (a) When a closed corporation issues its securities for any consideration other than money, before issuing the securities, the board of directors shall determine the fair value to the corporation, in monetary terms, of any such consideration.

(b) In the absence of fraud this determination shall be conclusive.

Comment: This section in substance reiterates Section 1112 of the General Corporation Law. Since it appears in the body of the Closed Corporation Law, all the sanctions of this law become applicable to enforce the obligation of the directors to carefully examine such property and to act in good faith.

4710 CaI. Admen. Code \$\$ 368.2, 372.

4810 CAL. ADMINN. CODE $\$ 368$. 
3. Article Three. Certificates. Effective Transfer of Shares

Section 7230. Each certificate of closed corporation securities shall state:

(a) the name of the record holder of the shares represented thereby;

(b) the number of shares represented thereby;

(c) In letters not smaller than 12 point the following: CLOSED CORPORATION SECURITY. THIS SECURITY MAY BE VOID IF TRANSFERRED WITHOUT PERMIT FROM THE COMMISSIONER OF. CORPORATIONS, STATE OF CALIFORNIA.

Comment: The certificate itself must be identified as being a closed corporation. security. The warning regarding the possible need for a permit is intended to alert the potential buyer to contact the Division or to ask a lawyer for information. The effectiveness of this requirement is himited since it depends on the initiative of a possibly unsophisticated buyer in question. But noncompliance is, at least, easily proved.

Section 7231. (a) Each closed corporation security certificate shall be signed by the president and the secretary of the corporation, or by the director sole, ${ }^{49}$ or the officer sole. ${ }^{50}$

(b) No facsimile signatures shall be used.

Comment: This section restates Section 2406 in a forn suitable for the Closed Corporation Law.

Section 7232.

Form of Closed Corporation Securities Certificate. XYZ, A CLOSED CORPORATION

NO. SHARES...............

This certifies that $\ldots \ldots \ldots \ldots \ldots \ldots \ldots$ is the record holder of $\ldots \ldots \ldots \ldots$ shares of XYZ, A CLOSED CORPORATION, transferable on the books of the corporation in person or by duly authorized attorney upon surrender of this certificate properly endorsed.

SEAL

Secretary .............. President............... CLOSED CORPORATION SECURITY. THIS SECURITY MAY BE VOID IF TRANSFERRED WITHOUT PERMIT

49 See \$ 7312 infra and accompanying comment.

50 Ibid. 
FROM THE COMMISSIONER OF CORPORATIONS, STATE OF CALIFORNIA.

Section 7233. (a) The secretary shall make a copy of any closed corporation security certificate issued.

(b) Such copies shall be kept as part of the corporate records.

Comment: This is merely a mechanical aid in establishing lost certificates.

Section 7234. (a) Transfer of a closed corporation security becomes effective when the secretary of the closed corporation has received a certificate, duly endorsed or accompanied by proper evidence of succession, assignment, or authority to transfer.

(b) After so receiving a certificate the secretary shall cancel it, issue a new certificate, and record the transaction on the books of the corporation.

Comment: This section removes the protection given to bona fide purchasers by Section 8301 and related sections of the California Commercial Code. Endorsement: is not sufficient to have any legal effect as to transfer. Transfer becoines effective when the secretary has actual possession of the certificate. There are two reasons for this provision: (1) A potential transferee of a closed corporation security must be able to find out with certainty whether he may buy the security without a transfer permit. His seller, whether the corporation or another shareholder, needs the same certainty. (2) It makes the securities unacceptable on securities markets.

\section{Article Four. Stated Capital}

Section 7240. (a) Every closed corporation shall have a stated capital.

(b) This stated capital consists of the following:

(1) the aggregate amount, in dollars, of the consideration actually received by the corporation for all shares issued from time to time;

(2) Any amounts transferred from earned surplus to stated capital
(A) upon declaration of a share dividend, or
(B) by resolution of the board of directors.

Comment: The Closed Corporation Law abandons the par value concept. It can serve no useful purpose in this law because a closed corporation cannot have preferred stock, or other stock redeemable at a 
fixed price, and I can think of no other instance where the recital of par value would reflect more than the amount of money presumably paid when the stock was originally issued. Moreover, a recital of par value can be misleading to the unsophisticated investor.

The concept of paid-in surplus is tied to par value and disappears with it. It likewise would serve no useful purpose in the closed corporation law because closed corporation shares are not publicly traded, and thus there is no need for a fund from which dividends could be maintained in meager years.

Section 7241. The stated capital of a closed corporation shall not be less than two thousand dollars, in cash or its equivalent.

Section 7242. (a) Capital may not be reduced below the amount specified in Section 7241.

(b) The suffering of bona fide business losses shall not be deemed a reduction.

Comment to Sections 7241 and 7242: A minimum floor of capitalization is felt to be desirable.

Section 7243. A closed corporation shall not be required to comply with Sections 1908 and 1909, relating to certificates of distribution of reduction surplus.

Comment: The enforcement of proper distribution of reduction surplus by the treble damage provisions (Section 7341(d) (11-12)) of the Closed Corporation Law is probably sufficient.

\section{Article Five. Additional Filing Requirements}

Section 7250. All matters required to be filed under this article are open to inspection by the public.

Section 7251. Within thirty days from the date of incorporation, every closed corporation shall file with the Secretary of State, with the Commissioner of Corporations, and with the Clerk of the County of its principal place of business, its business address and a hist of its shareholders, directors and officers, giving their full name, date and place of birth, and then current address.

Section 7252. Every closed corporation shall file an amended list with all officials named in Section 7251, within thirty days after any change in the list filed under Section 7251 have occurred.

Comment to Sections 7250, 7251 and 7252: Business can and should be conducted above board. This principle includes full knowledge of the identity of all participants. It might be said that since the advent of the large-scale use of the corporate form the good name of a businessman 
has considerably less effect than in the old days. It is easy for the dubious operator to hide behind a corporate name, or rather a haze of corporate names of various interrelated corporations, and the names of accommodation directors and occasionally perhaps even accommodation shareholders. There is no legitimate reason for anonymity of the persons ultimately responsible for the actions of a corporation. Anonymity is not a necessary concomitant to limited liability. To the contrary, some continental laws, drafted at a time when a businessman's good name still had meaning, forbade the use of a cover name. ${ }^{61}$

Section 7253. Every closed corporation shall file with the Secretary of State a copy of its by-laws and of any instruments required by Section 7310 .

Section 7254. Any amendment to the by-laws shall be filed within ninety days after its adoption.

Comment to Sections 7253 and 7254: Corporate by-laws have grown from what may be described as the equivalent of "rules and regulations" of the board of directors for the internal conduct of the business of the corporation into a receptacle of basic shareholders' rights and limitations on directors' powers, equivalent in importance to the provisions set forth in the articles of incorporation. As a logical consequence, the Closed Corporation Law requires that the by-laws, being of equal dignity and importance with the articles, though covering a different area, must also be made a public record.

\section{Article Six. Prohibited Selling Methods}

Section 7260. A closed corporation shall not offer to any of its shareholders, or prospective shareholders, any bonus or any other consideration besides its securities.

Comment: This section codifies regulation $345 .^{52}$ The purpose is to prevent circumvention of the equal rights for equal value rule by some scheme of bonus shares or discounts or anything else that would lead to the forbidden result.

Section 7261. (a) An agreement to form a closed corporation may be negotiated without permit from the Commissioner.

(b) Any party to such an agreement may enforce it against any other party.

(c) Any such agreement is voidable at the instance of the subscriber, if the agreement, when consumated, would result in noncompliance with any provision of the Closed Corporation Law.

61 Gesetischatit MIT BeschränKTter Haftung-Gesetz § 4. (Hueck ed. 1964).

6210 CaL. ADMTN. Code $\$ 345$. 
Comment: An agreement to form a closed corporation needs no permit and is enforceable if the agreement would not lead to noncompliance with the Closed Corporation Law. It is useful in the formation of a venture to lave a binding contract for all the parties participating, so that none of them can back out during the period required for completing the organization. This is especially necessary for the formation of a closed corporation because it comes into existence only after the entire consideration for the securities has been received by the corporation and the securities have been issued.

Section 7262. (a) A closed corporation shall not offer or sell its securities through or with the assistance of a broker or an agent, as defined by this code,

(b) and shall not make or permit any charge to be made in connection with the issuing or transferring its securities.

Comment: The purpose of this section is to underscore the prohibition against public marketing of closed corporation securities (subdivision (a)), and to prevent circumvention of the equal rights for equal value rule (subdivision (b)).

Section 7263. No closed corporation sliall offer its securities for sale through any advertising.

Comment: The purpose of this section is likewise to underscore the nonpublic character of a closed corporation. A closed group requires no advertising.

\section{Chapter Three. Operation. Fundamental Changes. Dissolution.}

\section{Article One. Shareholders and Directors}

Section 7300. (a) Every shareholder, director, or officer of a closed corporation has a fiduciary duty toward all other shareholders, directors or officers, with respect to any matter connected with the business or the property of the corporation.

(b) The standard of conduct under this duty slall be at least as high as that of a director under the General Corporation Law.

(c) Without limiting the scope of the duty imposed by Subdivision (a), a shareholder, director, or officer of a closed corporation is entitled only to such benefits from any transaction connected with the business or the property of the corporation, as inures to him as his proportionate slare in the ownership of the corporation, or under express provisions of a written contract between him and the corporation.

(d) In case of ambiguity such contract provisions shall be construed in favor of the corporation. 
Comment: There is frequently no distinction between the actual powers of a majority shareholder and a director in a small corporation. This has been recognized elsewhere, ${ }^{53}$ and a fiduciary duty has been imposed on dominant shareholders under certain circumstances under the new New York Business Corporation Law. ${ }^{54}$

The proposed section imposes a duty at least equivalent to that of a corporate director under current California law on both majority and minority shareholders, as well as on officers and directors. No reason appears why officers and minority shareholders should not be subject to the same obligation of utmost propriety in dealing.

As the California law in this field develops over the years under the General Corporation Law, the proposed provisions will ensure that at least an equal degree of honesty is required in the dealings of the participants of closed corporations among each other. No precise definition of the extent of a shareholder's fiduciary duty is possible. This problem must be left to the courts to be solved on a case by case basis.

The higher standard of conduct is required from participants in closed corporations to protect the passive investors who normally would enjoy the protection provided by the Division of Corporations.

Section 7301. A closed corporation shall not make any loans of money or property to, or guarantee the obligation of, any of its shareholders, directors, or officers.

Comment: The purpose of this section is to eliminate entirely a cause of potential breaches of fiduciary duty which is currently one of the most frequent sources of "alter ego" litigation. Few good business reasons can be adduced why it should ever be to the advantage of a normal business corporation to lend inoney to its shareholders, directors or officers, except as additional remuneration. This, however, may be done equally well by an increase in salary. Measured against the risk of abuse, the business benefits are snall.

Section 7302. (a) A closed corporation shall not enter into any contract with any of its shareholders, directors, or officers, without prior approval of two-thirds of its shareholders.

(b) Such approval shall not relieve any shareholder, director, or officer of the fiduciary duty imposed by Section 7300 .

Comment: Contracts between the corporation and its shareholders, directors or officers, especially employment contracts, are a type of "loophole" in the protection of passive investors. At present, such con-

53 Pepper v. Litton, 308, U.S. 295, 306 (1939) (dictum); Zahn v. Transamerica Corp., 162 F.2d 36 (3d Cir. 1947).

54 N. Y. BUSINESS CoRp. LAW § 620(f). 
tracts are normally studied closely by the Commissioner's staff. ${ }^{55}$ Therefore, it was felt necessary to impose the requirement of an extraordinary majority vote for approval. At the same time it was necessary to make unmistakably clear that the majority, no matter what its size, would in no event be relieved of its fiduciary duty.

Section 7303. (a) When acting without a meeting the written consent of the holders of at least two-thirds of the shares of a closed corporation shall be sufficient for any action within the powers of shareholders.

(b) The written consent shall be obtained as follows:

(1) The board of directors, or any shareholder, shall mail to each shareholder a request to consent.

(2) The request shall fully describe the action to be taken.

(c) Action is taken when requests to consent signed by the holders of at least two-thirds of the shares have been filed with the secretary.

(d) Failure to return a request is a nay vote.

(e) If at least one-third of the shareholders file with the secretary a written demand for a meeting, then the action in question may not be taken by written consent until a meeting has been held.

Section 7304. (a) When acting without a meeting the written consent of at least two-thirds of the directors of a closed corporation shall be sufficient for any action within the powers of directors.

(b) The written consent shall be obtained as follows:

(1) The chairman of the board, or any director, shall mail to each director a request to consent.

(2) The request shall fully describe the action to be taken.

(c) Action is taken when requests to consent signed by twothirds of the directors have been filed with the secretary.

(d) Failure to return a request is a nay vote.

Comment to Sections 7303 and 7304: A small group engaged in a business or a joint venture would be unnecessarily hampered by a requirement limiting action to formal meetings or unamimous consent. The existence of the strict fiduciary duty, together with the absence of a statute of limitations, and the two-thirds majority required, will all tend to prevent abuse of this convenient method of obtaining corporate action.

${ }^{65}$ This practice is not specifically authorized by the regulations but is customarily followed. 
Section 7305. To act on the matters enumerated in Section 2201 except subdivision (e) the vote in person or by proxy of the holders of at least two-thirds of the shares of a closed corporation shall be required.

Comment: The extraordinary majority for all fundamental changes except dissolution was felt advisable as protection for minority shareholders. Dissolution was excepted because increasing the difficulty of dissolution is undesirable for closed corporations. Because of the small number of persons involved in running a closed corporation, personality conflicts may grow to major proportions and produce a deadlock. Dissolution may be the only way to resolve the deadlock and it should not be made more difficult than it is for a general corporation.

The General Corporation Law provides for a vote of two-thirds of the shareholders of every class for merger or consolidation (Section 4107), but permits sale of all assets by a simple majority of the voting power (Section 3901). An unwilling minority would be equally adversely affected by an unwanted sale of assets as by an unwanted merger.

Section 7306. The by-laws of a closed corporation may be amended only with the vote or written consent of the majority of the shareholders.

Comment: By-laws often contam very substantial rights. The directors should not be permitted to make changes in these. It is proper that the board of directors should make rules for the conduct and delegated powers of those responsible to them. To permit them to change the rules under which they are responsible to the shareholders is not sound policy.

Section 7307. (a) A closed corporation having less than three shareholders may liave less than three directors.

(b) Unless the by-laws of sucl a closed corporation provide otherwise, one director shall exercise the powers of the board of directors.

(c) This director shall be known as the "director sole."

Comment: This section seeks to solve the problem of the corporation with two shareholders, or a single shareholder. It would force the parties to agree to give legal power to act to one man. He is strictly responsible as a fiduciary, and the corporation will not be deadlocked in its day-today business. There should be no accommodation directors under the closed corporation law, as a practical matter, because the potential liability, for a person who does not know what is happening, is too great.

This section, in effect, removes the minimum quorum of Section 816 and replaces the majority requirement of Section 817 . 
Section 7308. Unless the by-laws of a closed corporation having less than three shareholders provide otherwise, the director sole shall exercise the powers of the corporate officers.

Comment: This section replaces Section 821 as to corporations having one or two shareholders. Under the Closed Corporation Law accommodation directors and officers are equally unsafe.

Section 7309. The by-laws of a closed corporation may, in any manner not in conflict with the provisions or the purposes of the Closed Corporation Law,

(1) restrict the discretion of the board of directors (or of the director sole) in the management of its business;

(2) bind named shareholders to vote their shares as a unit for the election of directors, for a period not to exceed ten years.

Comment: The provisions of this section have been adapted for the Closed Corporation Law from Section 55-73 of the North Carolina Business Corporation Act. ${ }^{56}$ Restrictions on the discretion of the board and voting agreements are accepted methods of minority protection in small corporations. ${ }^{67}$ They are not in conflict with the concept of the corporation as a separate legal entity. The North Carolina act, in addition, permits special agreements which could turn the corporation substantially into a partnership; for example, profits may be divided in a different proportion than share ownership. ${ }^{58}$ Such a provision in the Closed Corporation Law would, however, open the door to unreasonable promoters' profits.

The proposed Closed Corporation Law offers considerable flexibility for conducting small business in corporate form. The directors' discretion may be limited; voting agreements are enforceable. A one-man board may operate through several officers, or a board of several directors may operate through one officer, and so on. Within the limits of the fiduciary duty imposed by Section 7300 and the requirement of Section 7302 that two-thirds of the shareholders approve employment contracts, there is flexibility as to salaries of officers and employees. Those who feel that this is not enough flexibility must continue to use the partnership form. Some price for limited liability must still be paid. This price is the requirement of formalized conduct of the corporate business to protect the public.

It may be desirable from a businessman's point of view to have

go N. C. Gen. Stat. Ch. 55, \$\$ 55-1 to 55-175 (1965). See 1 O'Neal, Close CorporaTIONS § 1.14 (1958).

571 O'NEAT, op. cit. supra note 56, \$ 1.12 .

58 N. C. Gen. StaT. $\$ \$ 57-73(b)$ (1965). 
limited liability, and to have in addition all the advantages of a partnership, such as ease of dissolution, freedom from formalized conduct of the business, and wide latitude in the distribution of profits. But the partnership characteristics just enumerated are incompatible with the concept of the separate corporate entity. To permit the corporation substantially to copy partnership forn, as the North Carolina act appears to do, would permit the incorporators to use the corporation as their alter ego.

The proposed Closed Corporation Law has attempted to give greater flexibility for the operation of small busmess in corporate form, but it strictly adheres to the concept of the separate legal entity of the corporation and to all subsidiary concepts which flow from this. This concept has been tried and tested, and has been found compatible with the public interest. To permit the fluid types of arrangement frequent in partnerships, and at the same time to give limited hability to such an organization does not appear to be safe or sound.

Section 7310. None of the provisions referred to in Section - 7309 are valid, unless they are

(1) set forth in the by-laws, or

(2) incorporated by reference into the by-laws, and an executed copy of the instrument so incorporated has been filed with the Secretary of State.

Comment: This section extends the disclosure requirement of Section 7253 to the special control structures permitted by Section 7309. A person dealing with a closed corporation must have the right to know who is ultimately responsible for the corporation's actions, and what are the limitations on the powers of the persons with whom he is dealing.

Section 7311. For purposes of the Closed Corporation Law the term "Articles" as used in Section 803 includes the by-laws and any matter incorporated into the by-laws.

Comment: This section extends the effect of Section 803 to closed corporations. It makes clear, also, that Section 7310 gives the persons dealing with a closed corporation the ability to ascertain the extent of authority of the particular representative of the closed corporation with whom they are dealing, but does not impose upon them the duty to ascertain, at their peril, such a person's authority.

Section 7312 . The by-laws of any closed corporation may provide

(1) that the powers of the board of directors shall be exercised by a director sole, and 
(2) that the powers of the corporate officers shall also be exercised by the director sole; or

(3) that the powers of the corporate officers shall be exercised by one person, known as officer sole.

Comment: This section is intended to afford flexibility in the management structure of a closed corporation. Any closed corporation may use the vehicle of the "director sole" or the "officer sole" to balance the powers of majority and minority shareholders, or for other purposes. A board of three, for example, may prescribe policy to an "officer sole," who would be responsible for the execution of policy. Alternatively, a "director sole" may set policy which will be executed by several officers. One man could serve as both "director sole" and "officer sole"; this arrangement might have special appeal to the one-shareholder corporation.

Section 7313. Section 2214, relating to fixing a date for determination of sliareholders of record does not apply to closed corporations.

Comment: Section 2214 is designed for corporations with numerous shareholders, spread nationwide, where the three-day deadline of Section 2215 may not be sufficient. In a closed corporation, since no transfer of securities becomes effective before the secretary has received the certificate under Section 7234, such a provision is not necessary nor desirable.

Section 7314. Every closed corporation having ten or more shareholders shall send an annual report to each shareholder not later than 120 days after the close of the fiscal or calendar year.

Comment: This section makes an annual report for closed corporations over ten shareholders mandatory. Once the number of shareholders exceeds ten the probability that there are several passive investors among them is great. These must be kept informed.

\section{Article Tro. Inspection of Records}

Section 7320. (a) Every shareholder of a closed corporation has an absolute right of inspection identical to that of a director under Section 3004.

(b) An inspecting shareholder is liable to the corporation for treble the damages resulting from any intentional or negligent disclosure of any trade secret belonging to the corporation.

Comment: Since the number of shareliolders in a closed corporation is small and since their legal duties and liabilities are similar to those of 
directors in a general business corporation, it follows that closed corporation shareholders must be given the same inspection rights as directors. This has been done by extending the director's rights under Section 3004 to the shareholders. An inspecting shareholder acts, of course, subject to his fiduciary duty. Subdivision (b) expressly names one major area of application of this duty.

Section 7321. Shareholders, directors or officers of a closed corporation shall render on demand true and full information of all things affecting the corporation to any shareholder or his legal representative.

Comment: This section was adapted from Section 15020 of the Uniform Partnership Act. ${ }^{59}$ Inspection of the records may sometimes not be sufficient to give a shareholder of a closed corporation the information he desires, for example with regard to a pending business transaction. Since the shareholder might be held hable for a noncompliance flowing from a transaction, it is necessary that in this respect he should have the rights of a partner.

Section 7322. In addition to any other liability, a closed corporation which has wrongfully withheld the right of inspection from any of its shareholders is liable for actual attorneys' fees and costs reasonably incurred by him in enforcing the right.

Comment: The inspection right is essential to a shareholder in a closed corporation, due to his potential personal liability. The entire burden of interfering with this right in an unlawful manner must therefore be put on the corporation.

\section{Article Three. Dividends}

Section 7330. (a) A closed corporation may declare and pay dividends, whether in cash, property, or shares of the corporation, only as follows:

(1) out of earned surplus.

(2) out of surplus arising from reduction of stated capital.

(b) The corporation shall give notice of the source of the dividend to the shareholders prior to, or concurrently with payment.

Comment: The sources of dividends for closed corporations have been reduced from the four allowed by section 1500 to two: earned surplus and reduction surplus. Paid-in surplus could not arise in a closed

59 CAT. CoRp. Code $\$ 15020$. 
corporation since the par value concept has been abandoned. "Nimble dividends" are not desirable for a closed corporation since the nimble dividend presupposes an appeal to passive investors.

\section{Article Four. Liabilities}

Section 7340. The shareholders of a closed corporation are personally liable for any unsatisfied judgments against the corporation for wrongful death or personal injury.

Comment: This section is designed to encourage adequate insurance coverage by closed corporations whose assets would be insufficient for self-insurance.

Section 7341. (a) Any person who suffers any damages due to a violation of any of the sections listed in subdivision (d) may bring a treble damage action under Section 7107 against the persons who committed said violations, and such persons are jointly and severally liable.

(b) No person wholly or partially legally responsible for such violation may bring such action.

(c) Institution of criminal proceedings, where applicable, shall not be a condition precedent to the action permitted by subdivision (a).

(d) The sections to which this section applies are:

(1) Section 1307, relating to issuance of unauthorized stock;

(2) Section 1308, relating to issuance of stock with intent to defraud;

(3) Section 1309, relating to fraud in subscription for stock;

(4) Section 1501, relating to declaration of dividends when unable to meet debts;

(5) Section 1502, relating to declaration of dividends out of unreahized appreciation;

(6) Section 1504, relating to declaration of dividends in in general;

(7) Section 1505, relating to declaration of share dividends out of unrealized appreciation;

(8) Section 1510 , relating to unauthorized dividends received by shareholders;

(9) Section 1511, relating to fraudulent declaration of dividends;

(10) Section 1715 , relating to shareholder's unlawful sale of shares to the corporation; 
(11) Section 1906(a), relating to distribution of surplus from reduction of stated capital;

(12) Section 1907 , relating to withdrawal of reduction surplus when unable to meet debts;

(13) Section 3018, relating to false statements and entries in documents;

(14) Section 3019 , relating to false statements affecting the value of shares and to refusal to make books or post notices required by law;

(15) Section 3020, relating to fraudulent receipt or possession of property and falsification of records;

(16) Section 3021, relating to exhibition of false documents to public officers;

(17) Section 3022, relating to unauthorized subscription of names;

(18) Section 3904, relating to statement in sale of assets that assets sold are less than substantially all assets;

(19) Section 5000, relating to distribution of assets on dissolution;

(20) Section 5001, relating to adequate provision for payment of debts on dissolution;

Comment: The purpose of the section is to extend the Closed Corporation Law's preference for restitution to all situations in which the legislature in the General Corporation Law has seen fit to impose criminal penalties, or simply to prohibit certain acts. Proof beyond a reasonable doubt in criminal actions is very difficult in some of these situations. The lesser evidentiary burden in a civil proceeding and the substantial amount of money likely to be lost by the responsible individual may be expected to act as more of a deterrent than the risk of criminal penalty.

At this point it may be worthwhile commenting on the treble damage provision. Its basic purpose is to "encourage" compliance with the law. It is in addition an attempt to provide some rough measure for making a victim of an infraction whole. Presently we measure the damages which directly result from the forbidden act. We conveniently ignore the cost of recovering these damages which certainly would not have arisen but for the forbidden act, such as loss of time, cost of investigation, cost of expert witnesses, loss of earnings and the like.

It is hoped that the treble damage provision will assure each deserving claimant competent legal counsel and still leave sufficient funds recovered to make good the actual loss. The section has been drafted to permit a treble damage action by all outsiders, and by all innocent insiders against the closed corporation and all responsible insiders. 


\section{Article Five. Entity Shareholders. Out of State Shareholders}

Section 7350. (a) "Entity shareholder" means an entity

(1) which holds any shares in a closed corporation, or

(2) has the right to appoint any director or officer, or

(3) has actual control of a closed corporation.

(b) "Remote entity shareholder" means an entity which owns or has actual control of an entity shareholder, whether directly or through a chain of controlled entities.

(c) "Controlling persons" means the twenty or less natural persons who hold the largest aggregate of ownership or actual control in an entity shareholder or in the ultimate remote entity shareholder in a chain of controlled entities.

Comment: The safeguards of the Closed Corporation Law would be rendered meaningless if they could be evaded by the creation of protective corporate layers. Very broad defimitions have been necessary to secure disclosure and responsibility of the persons or entities using the closed corporation. It must be left to the courts to determine "actual control" in borderhine cases, but the term would seem to include without question all forms of legal control currently known. The same comment applies to the term "controlled entities." All currently known legal mechamisms of entity chain control are included. In borderline cases we must rely on the courts.

Section 7351. (a) Every entity shareholder shall, within thirty days after becoming an entity shareholder, file with the officials named in Section 7251 a list of the names and addresses of its controlling persons and of all remote entity shareholders, if any.

(b) The hist covering remote entity shareholders shall include the names and addresses of the officers, directors, or equivalent officials and the twenty or less holders of the largest aggregate ownership or actual control in each remote entity shareholder.

Comment: The filing requirements of this section are designed to discourage the use of intervening entity layers. Since the hability is the same, with or without layers, entity shareholders may be persuaded to forego intervening layers.

Section 7352. Every foreign entity shareholder and every foreign remote entity shareholder shall qualify for transaction of intrastate business pursuant to Sections 6403 to 6408 .

Comment: Since the closed corporation is a suitable vehicle for joint ventures by corporate giants it is necessary to make foreign entities 
which use this vehicle amenable to California's control, and to service of process, just as would be done if they engaged directly in such ventures in the state.

Section 7353. The controlling persons of an entity shareholder or of a chain of remote entity shareholders are personally liable in any action under Section 7107 where the net assets of the entity shareholders or remote entity shareholders are insufficient to fully satisfy the claim.

Comment: This section puts the natural persons who control an entity shareholder, whether directly or through other entities, on a par with natural persons who are shareholders in a closed corporation.

Section 7354. A closed corporation shall file with the Secretary of State the name of an agent for service of process in the state and the irrevocable consent to such process for each of its shareholders, directors, or officers who reside outside of the state.

Section 7355. Every controlling person who resides outside of the state shall file with the Secretary of State the name of an agent for service of process in the state and his irrevocable consent to such process within thirty days after becoming a controlling person.

Comment to Sections 7354 and 7355: All persons ultimately responsible for compliance with the closed corporation law, whether natural persons or entities, must be subject to service of process in the state.

Section 7356. Every person required by this article to make any filing shall make an amended filing within thirty days after any changes in the original filing have occurred.

Section 7357. Any natural person residing outside of the state, and any foreign entity who ceases to be shareholder, director or officer, of a closed corporation may, subject to Section 6701, withdraw from the state by complying with all applicable provisions of Section 6700.

Comment: This section enables a foreign person or entity to formally "withdraw" from the state after his association with, and responsibility for, a closed corporation has ended. The withdrawal operates, of course, prospectively only.

I expect that the Secretary of State's office would set the applicable requirements of withdrawal for natural persons and for the various types of entities. 
Section 7358. No person who fails to comply with this article, and no person claiming any right belonging to or derived from such person, shall maintain any action or proceeding in any court of this state so long as this failure of compliance continues.

Comment: This section imposes the familiar penalty for failure to qualify. It is applicable to both natural persons and entities which fail to comply.

\section{Article Six. Merger and Consolidation}

Section 7360. A closed corporation may only merge into or consolidate with another closed corporation.

Comment: Since the Closed Corporation Law is in the nature of an exemption to the Corporate Securities Law and otherwise contains many special provisions, it is advisable to restrict combinations with corporations subject to different laws.

A closed corporation would have to change to an "open" corporation before a merger or consolidation with an open corporation would be permitted.

\section{Article Seven. Change to "Open" Corporation}

Section 7370. (a) A closed corporation may at any time incorporate under the General Corporation Law

(1) by filing amended articles of incorporation and

(2) by obtaining a permit to issue securities in exchange for the closed corporation securities issued and outstanding.

(b) (1) Incorporation under the General Corporation Law pursuant to this section does not relieve any successor corporation of any liability incurred during the time it was incorporated as a closed corporation.

(2) No limitations period is applicable to such liability.

\section{Chapter Four. Investigations}

Section 7400. The Commissioner of Corporations may investigate alleged violations of the Closed Corporation Law.

Comment: The district attorneys' offices throughout the state are generally not equipped to investigate violations of the Corporate Securities Law and related laws. The practice has been for the Division of Corporations to investigate the matter and advise a district attorney when 
a substantial violation is found. For the Closed Corporation Law this function has likewise been assigned to the Division.

Section 7401. For these investigations the Commissioner shall have the powers set forth in Chapter 3 of the Corporate Securities Law.

Section 7402. If a substantial violation is alleged, the Commissioner shall make an investigation.

Comment: The expected widespread use of the Closed Corporation Law makes it necessary that enforcement be highly effective. This section therefore attempts to limit the Commissioner's discretion to decline investigations. It may be expected that even an initial investigation by the Commissioner will cause the parties concerned to hasten to apply for a curative order, offering full restitution where necessary. I recognize, of course, that "substantial" is one of those words which merely describes the general result souglit to be achieved, and this section can serve no purpose beyond indicating that the legislature desired to hold the Commissioner's discretion within narrow limits.

Section 7403. If it appears that a substantial violation has occurred, the Commissioner shall certify the results of the investigation to the District Attorney of the County where the closed corporation involved has its principal place of business.

Comment: With the same purpose as Section 7402, this section attempts to limit the Commissioner's discretion by requiring that all substantial violations of the Closed Corporation Law must be certified to the appropriate district attorney. ${ }^{80}$

Section 7404. (a) If one or more defendants violate the Closed Corporation Law by related transactions in more than one county, the Commissioner shall certify these violations to the Attorney General.

(b) The type of violation described in subdivision (a) shall be known as "statewide violation."

(c) The Attorney General shall prosecute statewide violations in co-operation with the district attorney of the country in which he elects to prosecute.

(d) Venue for statewide violations is laid in

(1) the county where the closed corporation in question has its principal office, or 
(2) any one of the counties where any one violation occurred.

Comment: The statewide violation concept is mainly designed to reach the type of violation of securities laws where the monetary loss or other damages to any individual victim is small, but the law has been violated in numerous instances and the total gain to the violator from the many small violations is considerable.

As the recent example of the broker for a large mutual fund selling "front end loads" in California shows, at present one may safely disregard the law in a thousand instances, without fear of criminal penalty, so long as each violation is small enougl not to excite a jury. ${ }^{62}$ In my opinion a similar statewide violation clause would be desirable to strengthen the Corporate Securities Law.

\section{E. Chapter Five. Curative Powers}

\section{General Comment}

The Closed Corporation Law, hke the Corporate Securities Law, contains no limitations period. The slate is not automatically wiped clean.

As a general matter there is no reason why wrongdoing slould automatically cease to be wrongdoing by the mere passage of time, so long as a method is provided which permits the wrongdoer to set his own limitations date by giving back wliat he took wrongfully, or by mistake or neglect. Under a statute of limitations, the burden is on the person who has suffered the wrong to make the effort and expenditure required to pursue the wrongdoer for recovery. Any wrong that is less substantial in monetary terms than the attorneys' fees and other costs required for recovery can ordinarily be done safely to anyone but a wealthy per-

61 This term is applied to the practice of deducting from the first year's payment on a long-term installment contract a selling agent's commission based on the face value of the entire contract. The result of this practice is, if the purchaser defaults after making payments for a few years, he will lose a substantial portion of his investment. See The New Republic, July 2, 1966, pp. 13-14. The sale of "front end loads" is a violation of the Commissioner's regulations under $10 \mathrm{CAI}$. ADNTN. CoDE $\$ 353$.

62 The Commissioner had begun an investigation of Hamilton Management Corporation, the selling agent for Hamilton Funds, Inc., and had found evidence that salesmen for Hamilton Management had been selling shares without a permit and using the "front end load" device. Before any formal action could be taken, Hamilton Management disavowed the activities of its agents, offered restitution of the amounts paid (but without payment of any interest) to those buyers whom Hamilton Management admitted had been sold "front end loads," and withdrew from further selling activities in the state.

The Commissioner opposed the subsequent applications for new hicenses of agents who had sold for Hamilton Management. No action was taken against the company itself, even though it had had the use of the share purchasers' funds interest free for several years. 
son. Under a "curative system" the burden to set things right is on the wrongdoer. Statutes of limitations grew out of the human desire for certainty. But simply cutting off rightful claims is a crude method for achieving certainty. The burden to create certainty is more properly put on the person who feels the need for certainty most strongly. Let him come forward and offer such settlement as he may think the other party will accept as his due, and let him bear the costs involved.

The general consequence of the shift of the burden to secure certainty to the person who has the greatest doubts about the validity of his legal position would be greater overall adherence to the law. It would pay to follow the law scrupulously. Failure to seek the advice of conscientious and knowledgeable counsel would tend to be even more expensive in the long run than it is now. It would become the rare case where the attorney will advise, "If you sit tight for another two years you will not have to give it back."

This would, of course, be a change in the rules of the game. At present a type of premium is set on trying to take advantage of the other fellow, especially if you know that he may not have the funds to redress a slight wrong. The contrary incentive of a "curative system" would be powerful. Interest would accumulate, and soon an initially small wrong might be worth recovering. A man would never be secure in the possession of property acquired under circumstances of doubtful legality.

The specific curative system in question, combined as it is with the provision for treble damages, should facilitate a "survival of the fittest," the "fittest" taken in a sense of which Mr. Herbert Spencer did not even dream. His powerful, rapacious individuals would be the first to suffer economic destruction under a curative system.

Fifty years of experience under the California Corporate Securities Law have shown both that business can be conducted successfully, despite the absence of a statute of himitations for claims based on invalid securities, and that the overwhelming majority of California businessmen are honest and law-abiding in their dealings with corporate securities. California's spectacular growth was achieved under a law that did not even provide a convemient and inexpensive curative method: An entirely new permit is presently required to cure even the most technical defect in a prior permit.

The proposed Closed Corporation Law remedies this flaw in the California regulatory system by providing for a system by which noncompliance of any nature can be cured, where it is fair, just and equitable to do so. 


\section{Statutory Provisions}

Section 7500. (a) The Commissioner of Corporations shall have power to cure any noncomplances with the provisions of the Closed Corporation Law by issuing a curative order.

(b) The corporation, any holder of its securities or purported securities, or any person legally responsible for the noncompliance, may make application in writing for a curative order.

(c) The application must be verified.

Comment: The purpose of the section is to permit anyone who could become responsible for a noncompliance to cure it before the avalanche of a treble damage action hits him. If he has damaged another person, lie must make him whole. The more generous the initial offer of restitution the more likely its success. If the wrongdoer hesitates to make good voluntarily he very likely will eventually be required to pay a much greater amount.

Causation of the damages is the central problem. By the terms of the proposed statute, the Commissioner would liave to find whether damages have resulted from the noncompliance. In practice, this finding would be made by a hearing officer of the Office of Administrative Procedure.

Section 7501. (a) A curative order shall be issued only if the Commissioner finds that under the circumstances it is fair, just and equitable with respect to

(1) all holders of any purported securities,

(2) all holders of validly issued and outstanding securities,

(3) and all known creditors of the closed corporation.

(b) (1) If any damages have been caused to any person from the noncompliance in question, the commissioner shall not issue a curative order unless he finds that the applicant's offer of restitution will make all damaged parties whole.

(2) The Commissioner may, however, issue a curative order as to persons who agree to settle for less.

(3) A person is made whole if he has been reimbursed:

(A) for all damages suffered,

(B) with interest from the date the damages occurred,

(C) for costs,

(D) for actual attorneys' fees reasonably incurred, 
(E) for reasonable fees for licensed investigators where reasonably necessary,

(F) for all loss of time due to attending proceedings as a witness or party, and

(G) for any expenses of the nature described in (C), (D), (E) and (F) above, incurred in maintaining an action under Section 7107 or Section 7605.

Comment: (a) The factual situations of possible noncompliance are myriad. The legislature can therefore only provide a general standard for the exercise of discretion. Traditionally the general standard of discretion for the Commissioner has been described by the words "fair, just and equitable." These same words have therefore been chosen.

Creditors liave been included among the group the Commissioner must consider, because the Closed Corporation Law, in part, is designed for the benefit of the creditors.

(b) The Commissioner's discretion is expressly limited in the cases where a person has suffered damages flowing from the noncompliance. He cannot issue a curative order in sucl cases, unless the damaged persons lave been "made whole," as defined by this section. The Commissioner cannot force damaged persons to take less than the statute gives them. He can, of course, suggest a settlement that seems fair to him, but any person dissatisfied with such a settlement has lis remedy in court.

The definition of the term "made whole" is self-explanatory, except for one comment: Reimbursement for fees for licensed investigators is necessary, since the closed corporation is open to use by large nationwide corporations.

Section 7502. (a) A curative order slall not be issued, unless the Commissioner finds that all persons listed in subdivision (a) of Section 7501 have received written notice of the pending application and of their right to a hearmg

(1) by personal service as provided in the Code of Civil Procedure, or

(2) by registered or certified mail to their last known business and lome addresses, return receipt requested, showing to whom and when delivered, and

(3) none of these persons lave requested a hearing within thirty days after service or receipt of mailed notice. 
(b) The notice shall fully describe the circumstances of the noncompliance sought to be cured.

(c) A form of the notice proposed to be sent shall be attached to the application for approval by the Commissioner.

Comment: The notice provisions are self-explanatory. It seems likely that notice by mail will satisfy due process. ${ }^{63} \mathrm{~A}$ cautious applicant for a curative order will, of course, insist on personal service. If, however, the number of persons is very large, he may first try to give notice by certified mail and then single out for personal service only those from whom lie has not received a personally signed return receipt. A person who actually received a certified letter with the appropriate notice and signed a receipt therefor has surely been accorded due process. ${ }^{64}$

Section 7503. A curative order shall take effect as of the date

(1) on which each of the purported securities was actually issued, or

(2) on which the purported transfer took place, or

(3) on which any other form of noncompliance occurred.

Section 7504.

(1) If the Commissioner determines that he otherwise cannot fairly make the findings required by Section 7501,

(2) then he may order a hearing to be held on thirty days' written notice,

(3) even if none of the persons notified pursuant to Section 7502 have requested a hearing.

Comment: This section gives the Commissioner the power to call a hearing sua sponte. This may be necessary where the occasional unsophisticated passive investor fails to demand a hearing in a situation where the Commissioner has reason to suspect fraud or sharp practice, or even where it appears that the applicant is less than candid and the offer of restitution seems inadequate.

Section 7505.

(1) In connection with the issuance of a curative order, the Commissioner may impose such conditions and,

(2) may make such additional remedial orders as may be fair, just and equitable. 
Comment: This section gives the Commissioner leeway to develop a new body of administrative practice to deal with the various problems of noncompliance that may be expected to arise.

Section 7506. (a) The Commissioner shall render a written decision for each curative order granted or denied.

(b) The decision shall set forth

(1) findings of fact relating to the circumstances under which the application arose, and

(2) the reasons for any action taken by the Commissioner.

(c) The decisions shall be available to the public.

Comment: It may be expected that a considerable body of administrative practice will develop in connection with applications for curative orders. This section makes a chain of precedents available to the public to permit prediction of likely results in a general way. The strict doctrine of stare decisis is not applicable in the field of administrative action. ${ }^{65}$ Still it is preferable if the public has some method of orienting itself. The Commissioner does not act arbitrarily. Decisions fall into broadly similar patterns under similar factual circumstances.

Publication of the decisions would tend to produce greater uniformity in treatment by the various deputies. While processing permit applications as a deputy $I$ have personally found the occasional lack of written guidelines frustrating. There is no reason why the rationale of the Commissioner's decisions should be transmitted only by confidential memoranda or by word of mouth.

I again emphasize that the requirement for written decisions is not intended as a rigid himit on the Commissioner's discretion. Like a court, the Commissioner may occasionally reverse himself, or simply treat a case with an exceptional feature as an exception.

Section 7507. The issuance or denial of a curative order under section 7500 shall have no effect on the criminal liability of any person.

Comment: A curative order may be sought by an innocent shareholder of a closed corporation whose directors are guilty of criminal misconduct. Fairness may require that the order be granted, provided any damage to third parties has been remedied. Issuance of the order under such circumstances should not be understood as excusing the crim-

65 See 2 Davis, Adacinsstrative Law \$ 17.07-.08 (1958). 
inal misconduct. This section expressly assures that the wrongdoer remains liable for criminal penalties, where appropriate.

Section 7508. The fee for filing an application for a curative order shall be fifty dollars, plus a sum, as estimated by the Commissioner, to cover the actual expense of preparing for and of holding any hearing necessary in connection with the application.

Comment: The fifty dollar fee is designed to reimburse the Commissioner for the cost of processing the numerous routine applications which may be expected for curing minor neglects or mistakes. The cost of the more complicated applications which usually would require a hearing cannot be adequately gauged at this time. This will be a matter to be dealt with by administrative regulations.

Section 7509. (a) When an application for a curative order has been filed, the applicant may, in any civil proceedings pending in a court of original jurisdiction, move for a stay of proceedings with respect to any issue which turns on noncompliance.

(b) If the applicant is not a party to such proceedings he sliall be permitted to intervene.

(c) A copy of the application shall be attached to the notice of motion.

(d) Supplementary affidavits may also be attached.

Section 7510. (a) If the court finds that the application and affidavits, if any, state facts showing:

(1) that the Commissioner lias jurisdiction of the apphcation, and

(2) that there is a prima facie basis for the findings required by Section 7501 .

(b) then the court shall stay all proceedings relating to any issues which turn on noncompliance with any provisions of the Closed Corporation Law until the Commissioner has granted or denied the order, and the grant or denial has become final.

Comment to Sections 7509 and 7510 . These sections seem to take away what Section 7107 gave. To forestall a treble damage action all that seems necessary is to apply for a curative order and move for a stay in the treble damage action.

This is as it should be so long as the offer of restitution is designed to make the complainant whole, as defined in Section 7501(b)(3). The treble damage action is reserved for the recalcitrant wrongdoer. Ad- 
mittedly the effect of this system would be, "when in doubt, offer restitution." This is not so different from the present system, except that the defendant would be under greater pressure to settle.

Section 7511. (a) The Commissioner shall, without exception, cause all apphications for curative orders to be processed in the order in which they were filed.

(b) (1) For purposes of this section an application is processed in the order in which it was filed if it is assigned in such order to one of the persons who are customarily charged with the processing of such applications and is, without interruption, processed to completion by this person, his substitute, or any other person charged with such completion, excepting -

(2) any interruption in processing caused by any deficiency in the application, or by any other act or omission of the applicant, his agent, or any other person not employed by the Division of Corporations.

(c) Any person whose application for a curative order is not processed as provided by this section, may bring an action in the Superior Court of the county where he resides to recover from the Restitution Fund

(1) 100 dollars for each hour the filing of his application predates the filing of another application which in whole or in part was processed first;

(2) any damages caused to him thereby; and

(3) reasonable attorneys fees.

Comment: Not infrequently influential parties obtain preferred treatment from administrative agencies, be it due to the amount of money involved in the filing in question, or due to other factors. This is not as it should be. A small business needs administrative clearance for any given action as urgently as a large one. Time is money in either case. It is grossly unfair to permit a more powerful organization to come in ahead of a party who has been alert and has filed his application prior in time.

This section is designed to make it the unequivocal duty of the agency to serve the public on a first conje, first served basis, without exception.

\section{F. Chapter Six. Restitution Fund}

Section 7600. (a) A. closed corporation restitution fund is hereby created. 
(b) This fund shall be used to indemnify any person for losses suffered due to the failure of a closed corporation to comply with any provision of the Closed Corporation Law.

Section 7601. (a) The fund shall be administered by the Commissioner of Corporations.

(b) The Commissioner may make such regulations as may be necessary for the administration of the fund.

(c) The Commissioner shall be reimbursed by the fund for all expenses connected with its admmistration.

Section 7602. (a) Every closed corporation shall pay to the Secretary of State the fees provided by Section 26003 of this code in addition to the fees required for filing its articles of incorporation.

(b) The Secretary of State shall deposit these amounts, at least once a month, in the Treasury for the credit of the closed corporation restitution fund.

Section 7603. The Treasury shall disburse the moneys credited to the fund at the order of the Commissioner of Corporations.

Comment to Sections 7600, 7601,7602 and 7603. The idea of a restitution fnnd has been derived from the Real Estate Recovery Fund created by the 1963 legislature. ${ }^{66}$ Many sections of this Chapter have been adapted from that legislation. The Closed Corporation Law creates a substantial exemption from the Corporate Securities Law. An entire class of business is left to work out its intraclass relations within the new legal framework to be created by the Closed Corporation Law. The law is enforced by private actions of members of the class and such members of the general public as may occasionally become involved with a closed corporation. This is as it should be. "Mercliants" should be free to deal with "merchants" on their own terms within a general legal framework. But there is a problem when it comes to the relations of the "professionals" to the "nonprofessionals," in this instance the passive investors. Under the current law their interests are protected as a matter of public service by the Commissioner. Under the proposed law, the occasional passive investor who will become involved with a closed corporation would be relegated to exercise, at his own direct cost, the minimum quality control that is provided to the general public at a lesser cost by the Commissioner.

As already discussed in part II, the "built-in escrow" protection of the Closed Corporation Law would seem to give the same protection to passive investors as that currently achieved by the Division's practice

66 CAT. BUS. \& Prof. Code $\S \S 10470-83$. 
regarding "closed groups." Still we may feel uneasy about the occasional unsophisticated passive investor who will be involved with a closed corporation.

The restitution fund offers itself as a ready-1nade solution. The business community by now is accustomed to paying a certain amount for obtaining the privilege of limited liability. All that is necessary is to channel such fees in a different direction. Instead of applying them to maintain that part of the effort of the Division of Corporations which is allocable to examining securities to be issued to "closed groups," we could use these fees to create the restitution fund and to pay for its administration. In this manner the protection of the interests of the occasional passive investor would be assured for any damages flowing from a closed corporation's noncompliance with the ground rules.

The fund does not attempt to insure anybody against business risks; these will continue to be borne by the businessman.

Section 7604. (a) All moneys otherwise receivable by the restitution fund shall be paid into the general fund of the Treasury, so long as the balance of the restitution fund equals or exceeds five million dollars.

(b) The Treasurer shall keep account of all moneys so received by the general fund.

(c) Unsatisfied claims against the restitution fund shall be paid out of the general fund of the Treasury up to the total amount, without interest, received by the general fund pursuant to this section.

Comment: During the fiscal year 1965-1966 the Division issued 17,641 permits. The number of applications filed exceeds this figure by approximately ten per cent. ${ }^{67}$ Thus we may assume that approximately 19,400 fees were paid. I estimate that approximately one-half of the permits are "closed permits" issued to named issuees. The minimum fee for filing an application is fifty dollars. On these assumptions the fund may be expected to accumulate at the minimum rate of 500,000 dollars a year. Even if only about fifty per cent of the closed permits were supplanted by closed corporations formed under the proposed law, the fund would still grow annually by 250,000 dollars. Depending on the rate of claims, it might soon grow to substantial proportions. This creates a problem. Not all the inoney eventually accumulated may be needed. It is impracticable to make a pro rata refund to the contributing corporations. It would be an unfair windfall to some corporations to cut off or reduce collection of fees once the fund has reached a certain level.

67 Information received from the Sacramento Office of the Division of Corporations. 
I have therefore suggested payment into the general fund of the Treasury once the restitution fund has reached five million dollars. The general fund remains liable for shortages in the restitution fund to the extent of funds received over the years from closed corporation fees.

This arrangement will have to be reviewed after some experience with the administration of the fund has been gained. Perhaps it would be desirable to himit the effect of this section to a given number of years from the date the legislation is enacted to ensure reconsideration by the legislature.

Section 7605.

(a) (1) Any person

(2) who suffers any damages due to a failure of a closed corporation to comply with any provision of the Closed Corporation Law, and

(3) who is not legally responsible for the noncomphance,

(4) may file in the superior court of the county where he resides

(5) a verified application for indemnification from the fund.

(b) (1) A copy of the application must be served on the Commissioner and

(2) on the closed corporation involved, and

(3) proof of such service must be filed with the court.

(c) In addition, the Commissioner may serve the apphication

on any of the shareholders, directors, or officers of the closed corporation involved.

Comment: (a) Any person who suffers damages due to a noncompliance is to be protected. This includes all members of the public, whether natural persons or entities, as well as shareholders, directors or officers of a closed corporation who have not been held "legally responsible" for the noncompliance.

(b) The purpose of the fund is to make injured persons whole, quickly. Therefore service is required only on the closed corporation and on the Commissioner.

(c) The Commissioner has the power to serve additional parties whom he deems responsible to facilitate his subsequent treble damage action on the subrogated claim.

Section 7606. Within thirty days after proof of service under Section 7605 has been filed with the court, the court shall proceed with the hearing on the application. 
Comment: This section is copied from the Real Estate Recovery Fund. ${ }^{68}$ The purpose is to ensure speedy recovery for injured persons.

Section 7607. At the hearing the petitioner shall show that

(a) he is not legally responsible for the corporation's noncompliance;

(b) he is not a spouse of any person legally responsible for the corporation's noncomphance;

(c) he assigns to the Commissioner all his rights for any recovery under any provision of the Closed Corporation Law;

(d) $\mathrm{He}$ has posted a bond to guarantee court costs and reasonable attorneys' fees to the Commissioner, if the application slould be denied.

Comment: (a) For discussion of the problem of "legal responsibility" see comment to Section 7107 .

(b) The fund is subrogated to all causes of action a claimant against the fund would lave under the Closed Corporation Law. This enables the Commissioner to accumulate small claims against a repeating offender who was served and did not appear at the judicial proceedings. Knowing this provision, a well-advised one-time offender will be induced to move for a stay in the proceeding against the fund, apply for a curative order and offer full restitution, and be careful about compliance in the future. No tears need be slied for an offender who fails to seek the advice of competent counsel and thus gets hurt by the bite of these provisions.

Section 7608. At the hearing the court shall find

(1) whether the corporation's noncompliance caused the damages in question, and, if it did,

(2) the extent of the damages, and shall order the Commissioner to direct payment from the fund to the petitioner, together with costs and reasonable attorneys' fees, as determined by the court, and the amounts provided by Section 7501 for other expenses.

Comment: This section slould be subject to considerable litigation. No definition of causation is possible. The courts will have to resolve the issue of causation in the same way as they currently do in any tort case. The same is true of the measure of damages.

Section 7609. If the court orders payment pursuant to Section 7608 , the findings on which the order is based are res judicata 
against all persons served, or who have appeared, in the subsequent proceeding by the Commissioner against these persons.

Comment: The offending closed corporation is always served in any claim against the fund. The decision in the hearing is res judicata as to the closed corporation. Frequently a closed corporation in this situation will have no assets. This section gives the Commissioner the power to induce the legally responsible persons behind the closed corporation to make good on their obligations, by serving them pursuant to Section 7605 (c). If they do not appear or if they appear and lose on the merits, the Commissioner has established liability against them for his treble damage action under Section 7616.

Section 7610. The Commissioner shall oppose the application in any manner permitted by law for adversary civil proceedings, if he finds that granting the claim would not be fair, just and equitable under the circumstances.

Comment: This section gives the Commissioner the power to weed out sham claims.

Section 7611. (a) The Commissioner may, subject to court approval, compromise any claim made in an application under this part.

(b) A compromised claim establishes hability for purposes of Section 7609.

Comment: There will always be borderline situations in which compromise may be desirable. This section gives the Commissioner the necessary power. Three times the amount of any compromised claim may be collected by the Commissioner from legally responsible persons served who have not defended on the merits. Again it is hoped that the deterrent effect of this provision will prod the offender into an application for a curative order and a fair offer of restitution.

Section 7612. The maximum amount of damages, court costs, attorneys' fees or other expenses which may be recovered from the fund by any person shall be fifty thousand dollars for any failure or failures of compliance by any one closed corporation.

Comment: A maximum amount recoverable was felt necessary since initially the fund will not contain sufficient money. Most major claims may be expected to be brought by way of private treble damage action. Occasionally an impecumous offender will cause major damage. Here the injured parties will claim from the fund. The maximum amount ap- 
plies to all damages flowing from any noncompliance of which the applicant complains.

I have made no attempt to define "failure of comphance" or "noncompliance," since it is impossible to anticipate the myriad of factual situations that may qualify under these terms. It will be up to the courts to build a sound body of doctrine here.

Section 7613. (a) If the damages, costs, attorneys' fees and other expenses proved at the liearing on the apphication exceed fifty thousand dollars,

(b) and if the Commissioner thereafter recovers judgment and collects treble damages for the noncompliance in question,

(c) then the Commissioner shall direct payment to the petitioner of the damages, costs, attorneys' fees or other expenses not recovered from the fund.

Section 7614. (a) If, at any time, the money deposited in the fund is insufficient to satisfy, in whole or in part, any approved claim, then the Commissioner shall, when sufficient money has been deposited in the fund, direct such claims to be paid in the order in which they were originally filed.

(b) An unsatisfied claim shall bear interest at four per cent per annum.

Comment: Temporary insufficiency of funds must not defeat rightful claims. Such insufficiency could arise in the first years of operation before the fund has accumulated reserves.

Section 7615. (a) The Commissioner shall become subrogated to all rights of recovery which the petitioner has under this part.

(b) This subrogation

(1) becomes effective when the application is granted and,

(2) includes all such rights secured or accrued before that time.

Section 7616. (a) The Commissioner shall pursue all claims to which he may become subrogated under Section 7615 ,

(b) and shall, subject to Section 7613, deposit all moneys recovered in the Treasury to the credit of the fund.

Comment: Sections 7615 and 7616. See comment to Section 7607.

Section 7617. (a) The bond required by Section 7607 (d) shall be by a corporate surety and in an amount approved by the court.

(b) The bond shall guarantee costs and reasonable attorneys' 
fees to the Commissioner payable if the court denies the application with prejudice.

Section 7618. In lieu of the bond required by Section 7607(d) an applicant may post a casil bond of like amount, or such other security as the court may approve.

Comment: These sections are substantially copied from Sections 10481 and 10482 of the Business \& Professions Code.

Section 7619. Section 834 is not applicable to any action brought under Section 7605 .

Comment: See comment to Section 7109. 


\title{
California Law Review
}

\begin{tabular}{lll}
\hline Vor. 54 & DECEMBER 1966 & No. 5 \\
\hline
\end{tabular}

\author{
BOARD OF EDITORS \\ Care J. Senerker II \\ Editor-in-Chief \\ Chiarles H. Wirson, JR. \\ Managing Editor
}

\begin{tabular}{|c|c|}
\hline $\begin{array}{l}\text { BARBARA BRUDNo GARDNEl } \\
\text { Article Editor }\end{array}$ & $\begin{array}{l}\text { KENNETE A. GoLDMan } \\
\text { Note \& Comment Editor }\end{array}$ \\
\hline $\begin{array}{l}\text { DAVID ALAN LEIPLIGER } \\
\text { Article Editor }\end{array}$ & $\begin{array}{l}\text { AJEXANDER M. HEHMEYER } \\
\text { Note \& Comment Editor }\end{array}$ \\
\hline $\begin{array}{l}\text { David B. FromNMaYer } \\
\text { Research and Chief } \\
\text { Note \& Comment Editos }\end{array}$ & $\begin{array}{c}\text { ROBERT CarL HERR } \\
\text { Note \& Comment Editor }\end{array}$ \\
\hline $\begin{array}{l}\text { EDMOND R. MANWEXT } \\
\text { Book Review Editor }\end{array}$ & $\begin{array}{c}\text { SaAdDRA TERzIAN } \\
\text { Note \& Comment Editor }\end{array}$ \\
\hline $\begin{array}{l}\text { MYron G. SUGARMraN } \\
\text { Business Editor }\end{array}$ & $\begin{array}{c}\text { Tracy A. Westen } \\
\text { Note \& Comment Editor }\end{array}$ \\
\hline $\begin{array}{c}\text { JERRY J. BersaAN } \\
\text { Note \& Comment Editor }\end{array}$ & $\begin{array}{l}\text { STANLEY H. WIILIAMS } \\
\text { Note \& Comment Editor }\end{array}$ \\
\hline $\begin{array}{l}\text { GEORGE A. Cumang, Jr. } \\
\text { Note \& Comment Editor }\end{array}$ & $\begin{array}{c}\text { KELIY C. WoosTER } \\
\text { Note \& Comment Editor }\end{array}$ \\
\hline
\end{tabular}

Associate Editors

Robert ALAN BLUM Atan G. Cardton TOM A. Dowse Mitchaex A. Fischer

JoEN J. BENTLEY III Paul B. Bergacan StepHEN J. BisGeIER LAWRENCE L. CURTICE TMMothy Dregfus Michaet C. Ferguson Paut J. Fitzpatrick JANET FRIEDMAAN STEven H. Goldfarb AItson M. GREY
D.ANIEI S. Frost

Donald S. Greenterg Martin E. Harband Datias Holmas Riceard C. HuNT

\section{Candidates}

EMTEN HaIL Gugcerramse Robert ERNEST Gyemant ALAN E. HARRIS Dougras A. Haydex WIIJTAMS L. JAEGER Bianne Covington Jante Donatas Januta PaUL D. KayfeTZ AIAN S. KOENIO

MarjorIe DevereuX Administrative Assistant
STEVEN M. KIPperacan

Richard S. Platz WIIIIASM T. RDITALA SeIvyn Sembet
Mitchaei Justin Myers Gegrge Richard Poemater Joen F. Pritceard MARK Reutitnger DaNiEI U. SMith Jefreey David Sobec KrTstine Mary Strachan WIIITAM ROgER STRELOW WIIITAM T. VUKOWICH Peter K. Westen 